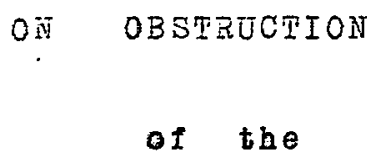

CENTRAL, ARTERY OF THE RTTINA
being a

THESIS

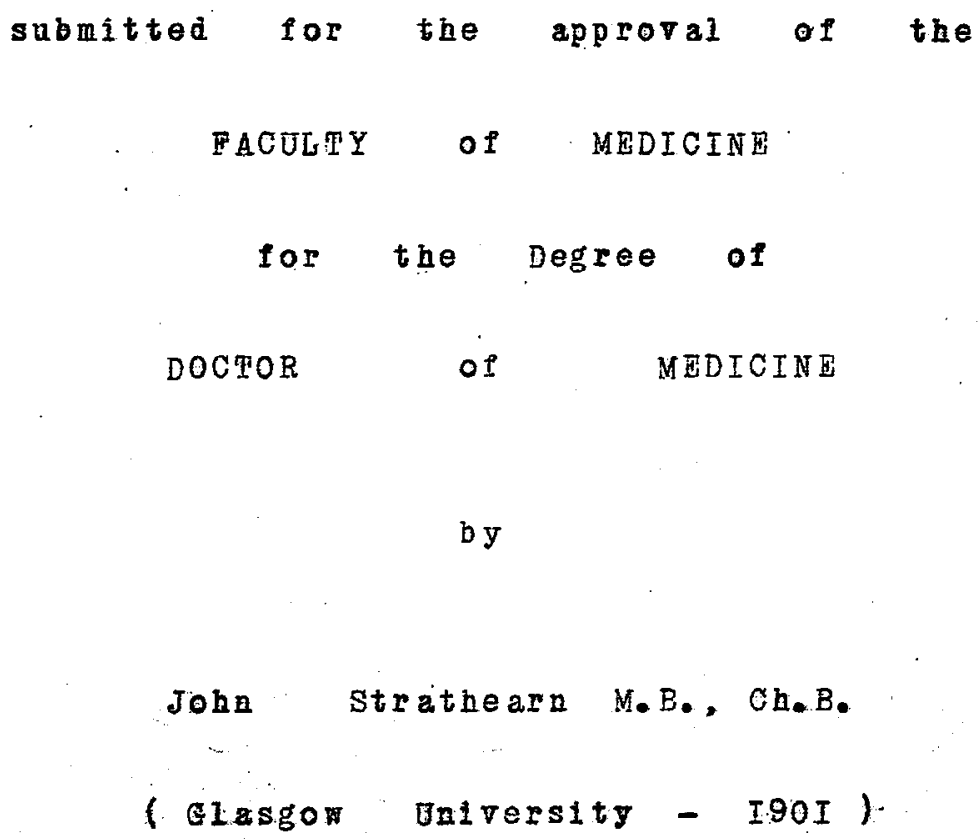


ProQuest Number: 27626700

All rights reserved

INFORMATION TO ALL USERS

The quality of this reproduction is dependent upon the quality of the copy submitted.

In the unlikely event that the author did not send a complete manuscript and there are missing pages, these will be noted. Also, if material had to be removed, a note will indicate the deletion.

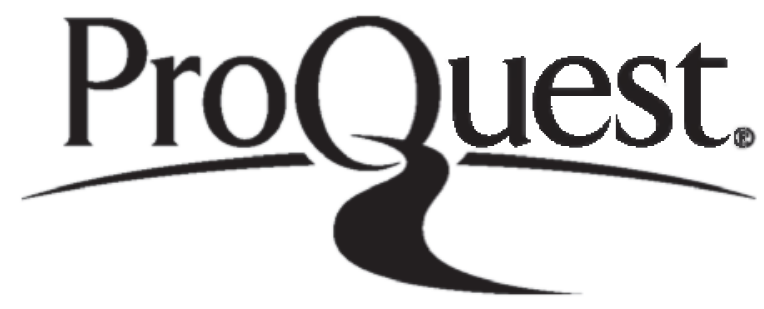

ProQuest 27626700

Published by ProQuest LLC (2019). Copyright of the Dissertation is held by the Author.

All rights reserved.

This work is protected against unauthorized copying under Title 17, United States Code Microform Edition (C) ProQuest LLC.

ProQuest LLC.

789 East Eisenhower Parkway

P.O. Box 1346

Ann Arbor, Ml 48106-1346 


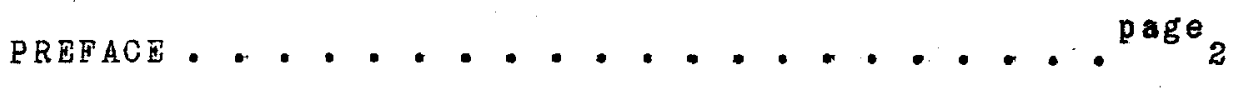
INTRODUCTION .................. 4 SECTION I -

Embolism ... • . . . . . . . . . . .

Eaemorrhage into Sheath . . . .... 10 Arterial disease ............. 13 Primary thrombosis ............. I6

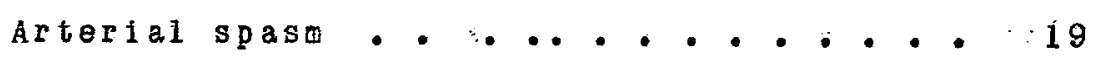
SACTION II - -

Case I . . . . . . . . . . . 39 Case II.................. 47 Case III . . . . . . . . . . . 57 Case IV................ 66 SECTION III - -

Critical consideration .......... 74 Conclusion ... ............ 93 REPRENCES - -

Section I................ 36 section III................. 94 


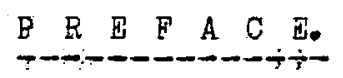

It is the purpart of this phesis to study the Girculatary Disturbances due to Obstruction of the Central Artery: of the Retina, Nith speeial reference to the. Et iology of this affection. After a short:introduction, I shall deal, thesty, in detall; with the various theortes as to its causation; secondly, give a conctsa report of cases of so-called groplism of the central: Artery of the Retina; that cane under wy onn observation; and lastly, enter into a critical consideration of the:subject.

The four cases, dealt with in the second section, were patients of the clasgow Eye Infirmary during my term, as House Surgeon; there; hence this gives some idea of the frequency of this affection, $3 s$ during that time (two years) 27,675 new cases were dealt with.

I am indabted to the Surgeans of the Infirmary for permission to uso these cases, and tor facilftes for pralonged exalnation to which their admission, as in-patients, contributed. I also consider myself fortunate in seeing these cases so 
soon after the anset of the obstruction.

The other cases; used tor 11 liustration and comparlson; were seen by me either in the Glasgow District Asyluns of Foodilee or Gartloeh, or in the Royal or westerin Infleparies of Gliasow.

\section{J. Strathearn.}

Hoodllee: Asylam,

Lenzie. 
INTRODUCT I O N.

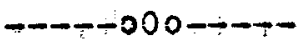

Probably the first recorded case of obstruction of the central. Artery of the Retina mas that of . Jaeger Who, in his work on Cataract, reports the case of a man, aged serentymtwo, who became blind overnight. The principal interest, to Jaeger in this case, seers to bave been the phenomenon of manifest airculation. in the blood vessels; with interruptions in the blood stream; but the cause of this does not seem to have been understood by bim.

Von Graefe, howerer, in 1859, publtshed a case of sudden blindness and made; for the first time, the ophthalmoscoplc diagnosis of "Embolism of the central Artery of the Retina." The ease is fatcly typloal although the ophthalmoscopic examiation was not made until eleven days atter the onset. He found the media clear, the volns: small. but fulter tarards tho periphery, the disc pale and the arteries much reduced. The man was also found to be suffering from aortic obstruction and endocarditis, so an exclusive dignasis of em- 


\section{(5.)}

bolism was made. On subsequent examination he noted an irregularity in the fliling of the velns, the breaking up of the blood covlmn into cylitider, the central region of the fundus cloudy and a cherry-red spot at the racula.

In the next fert years we bave reacods of sinilar cases by Schnelier; Blessig, and Liebrich. soon, however, observers began to question the adequacy of the original explanation and theories other than embolism of the central artery were advanced.

Magnus brought for ard the theory of Eaemorrhage into the Optic lerve Sheath; Steffan sought to show that the embolism was not af the Central Artery but of the ophthalinic Artery. The theory of Primary Arterial Thrombosis found many supporters; and lastly, some have sought. in arterial spasm, and others in arterial degeneration and disease; a cause for this obstruction. 


\section{$S \quad I C$ T. I $O$ N}

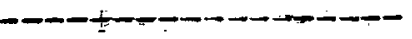

EMBOLI SM.

This is, at once, the oldest and most widely accepted theory and it must be admitted that in many cases it agrees with the clinical facts, Further, In the cases of Von Graefe, Schwigger, and sichel, an embolus in the lamina cribrosa was demonstrated as the cause of obstruction. A similar cause nas found in the more recent case of priestley Smith, the examination being wade. tour months after the accurrence. Gowars also reports a case, examined eight weeks after the onset, where a long granular embolus was found. Kern. has collected from the literature 16 cases: in which a pathological study has been made and in only three instances no embolus courd be discovered, In these three. cases. the lumen of the vessel was quite free. The suddenness of the onset; the absence of previous warning, the ophthalmoscopic picture of arterial obstructionat once suggest embolism and the finding of a source, sufficient for the production of an embolus, seems to clinch the diagnosis.

on more critical examination of the tacts, Is embolus an efeicient explanation? Hor doos it 


\section{$(7 \%)$}

happen that soon after the total. blockage of the artery we notice distinct evidence af circulation and, it may be, (even a moderate degree) fullness of the vessels. To account for this it is assumed (Schnabel and sachs) that the embolus is not suftioient to entirely block the vessel and hence some blood may gass. Elschnig equther elaborates this by supposing that at irst the iritition of the partial:embolus causes:it to be tightly gripped by the vessel watl, and; as the spasarelaxes, a certaln amount of blood bejins to pass. Though plauslble, this theory is in many ways untenable and as Haab states: "the idea of partial embolism is a very questionable condition and one that it is difficult ta understand. "n

$$
\text { on the other hand, in many cases, an }
$$

adequate cause for the origin of the embolus could nat be found. In Kern's work on the subject, out of a total of 54,800 cases at the clinic at Zurich, there were twelve cases of obstruction of the central artery and in only two of these cases was aI dudoubted source for the embolus found: that is, in 83 of the cases no positive source of the embolus was detected. Further, out of 83 cases of obstruetion of the artery, collected by him from the literature on the subject rhere a repart 
of the general condition was given, he found that in $60 \%$ of the cases no positive source for the embolus could be determined.

Again, is the existence or the finding of a heart murmur sufficient proof of an origin for an embolus? An objection, urgod by Reimar to the theory of embolus, is the lack of ophthalmoscapic avidence of such an obstruction. This evidence, horever, cannot; in the nature of things, be expected unless it is situated at the aisc or ts a branch embolism: with regard to this latter sore authars have described a white, yellonish-white or graywhite plug in a branch artery, whica was obstructed, and called it an eqbolus: but a study of degenerate vessels (retinal) in arter1o-sclerosis, Bright's disease etc.; where localised thicinglng of the Intimal and other coats is camon, raises a strong suspioion that their desariptions of appearances do. not marrant the name 'ombolus,' and, to say the least of It, thelr evidence is lacanclusive. of greater inporance is the fact that several authors, as Reimar and Haab, maintain that in all the pathological studies of cases reeorded, "ln not a single instance, not even in which it was rery likely ta be an embolus; has the proof of embolic nature been 
at all convincing." (Hab).

When we reflect, also, that the shortest

interval between the period of obstruction and the tide of enucliation was six weeks, and take into account the great changes that may tike place within tine vessels in this time, especially as enucleation was done; and can anly be justifiably done, for some lntercurrent affection, such as gliaucomaj we pust admit that it is no simple matter to state decisively the ature of the abstruction. Experimental work on this subject is of little value for; no one seeks to deny the possibility of embolism or that it could not give a very similar train of ophthalmoscopic appearances.

Hence Embolism of the Central. Artery of the Retina is; in many cases, a probable diagosis but, as a hypothesis; it is frequently so inadequate and un-needed that we ate bound to consider the passiblitiy of othor causes for this obstructian. 
EMBQLISM OF TEE OPHTHALMIC ARTERY.

The theory that obstruction of the

retinal arteries was dependent, at loast, in some cases on embolis.m of the ophthalmic artery ras brought formard by steffan in 1336.

There has been no anatomical evidence even to suggest this and in not one of the sixteen cases, where, as previously inentioned, pathologlcal examination was made, was this artery occluded. Indeed; when we consider the great anastomotic communications of the ophthalmic arteries with the branches of the external carotid; oven temporary cessation of the retinal circulation; due to embolism of the ophtratic artery, seems improbable. This hypothesis is then of herely historiaal. Interest.

AAEMORREAGE INTO TEE OPTIC NRRVE SHEATH.

In 1878, Magnus pubkished a case of sudden bitndness with subsequent restaration of gartale vision in the nasal balf of the retina. To explain this case he brought forward the theory that haemorrhage had occurred into the optic 
nerve sheath: the prassure of this abolished the power of nerve canduction and; to a certain extent, obliterated the artery: kater, absorption took place and those parts of the nerve, least infured; regained their function to same extent. This theory, like Steftan's, has no anatomical evidence to support it.

To be sure, haemorrhage into the sheath has been noted to have occurred, e.g., in rupture of an aneurysm of the idd le cerebral artery (Mackenzie), in rupture of an intra-cerebral extravasation lnto the meninges (vichel), and in Baemorrhagic Pachymeningitis (Vanz). But in these cases I can find no record of an ophthalmoscopic exantnation having been made or histary suggesting visual disturbance.

This lesion has been assured to be present after injuries, such as blows on the head or Ialls. For instance, cases have been described where blinaness came on a day or tro alter a fall and then gradual return of vision took place, this being accounted for by haemorphage into the optic nerve sheath. Whereas; in thase cases mhich lead ta optic nerve atrophy; damage to the nerve by fracture of the arbital bones was hore probable. 
Further, some cases of sudden blindness, in girlis, suffering from amenorrhoear have been described in which this diagnosis seemed to be a very likely one. Knapg deseribes a case of blindness that came on during the progress of whooping cough, where he ioud the disc white, the retinal arterias, invisible in one eyef and gere streaks in the other. He suggests, as one explanation, haemorrbage into the aptic nerve sheath. Landesberg describes a somerhat similar case of partial embolism probably due to this cause. Froin the foregoing it will be seen that this diagnosis can only apply to a limited number of cases; but it should be considered where we have a history of fijury, of amenorrhoea, of vicarious menstruation, of epistaxis or o.ther form of haemorrhage.

$$
\text { Clinloally, in addition to the other, }
$$
and ordinary, symptoms of obstiuction, sifght inperfection in the execution of lateral movements of the eyeball, with some degree of paln; rould to my wind; be suggestive. 
ARTERIAL DEGENERATION AND DISEASE AS. A CAUSE OF OBSTRUOTION.

Great advances have been made in recent years ith regard to our knowledge of arterial disease, especially in relation to the salier cerebral arteries. Unfortunately, a similar exhaustive, and systenatic, research (clinical and pathological) has yet to be carried out ith regard to the ocular ressels. True, much gaod mork has beex done by Thoma, Raehlmann, Hirschberg, Reimar, and others but there exist many gaps in our knowledge and we have irequently to assume analogous conditions which may, or may not, be fully warranted. In Bright's disease, more especially in the chronic granular kidney, there is undoubted clinical and pathological evidèce of arterial retinal change. Miaroscopiaaly, Bralley and Fdmunds have described this "as commonly a develapment of hyaline tissue, causing uniform thickening of the vessel wall, the change apparentiy occupying the middle coat; but sometimes said to start in the intima," This thickening necessarily diminishes the calibre of the vessel and, if great, way lead to its occlusion. 
There is an example of this from a section by Buzzard in Gower!'s Medical Ophthalmoscopy. Reimar, also, gives histological demonstration of this from a case of sudden bilindness where, in addition to a general narrowing of the calibre of the ocular arterles; through endarteritis, was seen at some places a complete obliteration of the lumen by. a localised intimal swelling. The kidneys showed chronic interstitial nephritis.

In senile angio-sclerosis somenhat.similar apporances, and results, have been noted: but instances of the purely seoile type are becoming rarer as our knowledge increases concerning the albuminuric; and the syphlitic, varieties. Sypho 11 is may produce changes that are very similar: to those seen in senile and albuminuric sclerosis. The syphilitic variety; which manifests itself as an endarteritis; or even periarteritis, may arise in. the early stage of the secondary period or at any subsequent time. The smaller arteries of the brain tn marked syphilitic arteritis may have their walls greatly thickened leading oven to occlusion, (obliterative arteritis). The vessels are frequently the seat of thrombosis.

There is also a group of cases where, 
for some unknown cause and apparantly unassociated with any particular diathests or disease, proliferation of the intima occurs. Physiologically, we see this process in the obliteration of the unbilical vessels and the ductus Botalli: and Thoma maintains that this process always ocours where there is a disproportion between the lumen of a vessel and the anount of blood passing through it.

The pathological variety has been described under varlous names lendarteritis obliterans, endarterttis proliferans etc.): it is sald to occur in adults between the ages of 30 and 60 and to be more frequent in wen than in women. Ofcourse; it may bo, as Reimar guggests, merely one of the manifestations of a general arteriosclerosis having a selective action on the smaller arteries. The retinal arteries, from their position and the Irequent movements to which they are subjected are peculiarly liable: to arterial disase.

We may take it for granted that a proliferating grocess ay, and in certaln conditions does; attack the retinal acteries: and we may surmise that this looal intinal swelling may of 
Itself so reduce the cal lore of a vessel that any diminution of blaod pressure, however arising, may perait of the approximation of the vessel warls and a stopgage in the current: if of short durationj causing only a transient obscuration; : but if more sustained; a peranent blindness: the functioning of the retinal cells, pithin certain limits, being more dependent on the continuity than on the quantity of the blood flow.

\section{PRIMARY THROMBOSIS.}

To explain the cases where. we have premonitory symptoms many authorities have attributed the obstruction to Primary Arterial Thrombosis. Such cases are those, to quote priestley smith, where we have a history of previous attacks of transient blinaness in the blind eye: a simultaneous atteck at blindness in the fellow eye: Qrevious; or subsequent; attacks of transient blindness in the fellow eye; especially: if the conditions of onset were the sare, in the permanent. as in the transient attack: and lastig, signs. of disturbance af the cerebral circulation at the onset of blindness, e. ge, gidilness, faintness, 
headache.: This is the teaching of most of our standard text-books on ophthalmology.

We must, then, discuss firstly the conditions in which arterlal thrombi are formed. So far as our present knowledge goes;. three classes of causes are assigned for thrombosis:-

(1) Alterations in the blood.

(2) Slowing and other irregularities of the current.

(3) Contact of the blood with abnormal surfaces.

Alteration of the blood is by itself, a posstible cause of thrombosis, admittedly rare. It 1s; in addition; ondy reasonable to expect taat this thrambotie disposition mould be general and hence take place p.rifarily in the veins and. further, it would lead to such vascular aisturbance that the question of its presence in the central artery of the retina be quite overshadored by its malign effects elsembere.

(E). Slowing or Irregularity in the: Blood Current.- Mere slowing of the eirculation does not suffice to form thrombi, for, as has been dewonstrated, $\theta \nabla \in n$ a stationary coliumn of blood in an artery or vain may remain fiuld for weeks. 
Sidilarly, the objection noted above also applies here, that a slowing of the current, dependent on a general cause, mould more likely, in the first p.race; affect the blood in the velns; and if a local one then the central veln and nat the central artery wauld be first affected; and as the actualfty of a primary thrombosis of the central: vein is very doubtful mueh mare than is: the occurrence of a primary thrombosis of the ceatral artery.

(3) Contact of the Blood with Abnormal Surfaces, - The jntegrity of the endotheliug is recognised as of the greatest foportance in maintaining the fluid state of the blood. Probably the commonest factor in impairment of the arterial mall is the presence of atheroma, especially in its liater stages and; unquestionably, is a frequent cause in inducing coagulation. On the other hand, arterlo-sclerosis, when unaccompanied by atheromatous or calcareous changes; is a very uncoman cause of thrombasis; and then it does occur; is probably more directly the result of circumstances, such as excesstue narrowing of the calibre of the vessel leading to diminution in the velocity of the blood stream etc. However; as yet; we have 
po expence of the existence of atheromatous changes, in, arteries of such small size as the central artery of the retina; and a narrowing., by arterio-scierosis etc., of such marked degree as to diminish the blood velocity and cause thrombosis; might of itself induce stoppage of the current (vide section arterial changes). Hence the thrombosis would not be the primary factor but a secondary effect ensuing after the retinal obstruction had occurred. Therefore, he mast conclude that Primary Throtibosis of the central artery of the retina is a possible, but not a very probable, cause; and further the symptoms, said to point to its existence, are more indicative of obstruction from disease of the arterial wall or from arterial spasi, as w11l be shown later; the thrombosis,. if it oceurs, being quite secondary and ensuing after the onset of the obstruction. OBSTRUGTION BY SPASM OF THE RETINAL ARTERIES. Since the publication, in 186z, of Raynaud's Thesis on local asphyxial and symetrical gangrene of the extremities, the condition of spastodic and recurrent contraction of the 
arterioles has been recognised. Amang bis later contributions on this subject was the observation that "occasionally, temporary alterations in the fundus oculi alternate or coincide mith manifestations of local asphyxia in the extremties:"

His first case was that of a man, aged 59, who, after suffering from attacks of local asphyzia of the fingers of one hand, then of the other and lastly of the peet, presented symptoms of visual disturbance: the eyegight, previously gaod in both, became dimmed, more especially in the left. Ophthalmoscopic examination showed that "the central artery of the retina and its. branches had very clear contours; and that they were defintely narrower round the papilla than at the periphery; here and there was a sort af partial constriction; the papilla was very clear; the veins were the seat of remarkable pulsations a litte Iater than the radial pulso." ..... "The central velu dilated and elongated itself so notably in the region of the papilla as to simulate a somll aneurysm, but the pulsation was also visible in the smaller veins." In the right the phenomena were similar but less marked. These examinations were verified by Galezowski. 
Eis second case nas that of a young man, aged $2 z$; and suffering from diabetes insipidus. He had local asphyxia of the upper extremities, and some blueness of the lace; during the attacks the radial pulse became very small, and at "the commencement of the eyanosis the patient complained of a notable obscuration of sight, which alsappeared when the face and hands returned to their natural colour." Panas observed that at the beginaing of the cyanotic attack the "arteries of the fundus ocull were deflnitely narrowed, "and that "when reaction occurred they became widened." "The retinal velns were turgid, but presented no appreciable pulsation."

II these cases Rayriad as amed that this contraction of the vessels ras a reflex act, being the result of a sensory excitation of the afferent nerves; an efferent impulse from the vaso-motor centre determining the contraction. So far as I am aware the anatomabl demonstration of vaso-motor nerves to the ocurar vessels has not yet been made, and the investigation of the human eye affords no proof that they are directly under the control of specific vasomotor nerves; but their existence is rendered 
very probable by numerous observations, botb ophthalmoscopic and experimental; upon men, and animals.

In 1848; Beid isolated the sympathetic from the vagus fibres in the cat, and showed that anly the sympethetic cased dilatation of the pupil on stimulating the peripheral end. Kuyper, In 1859, proved that in addition to dilatation of the pupil, contraction of the arteries: followed upon stimulation of the cervical sympathetic. The later observations of Parsons (1905) where on stimuration of the sympathetic in the dog, bigh up. in the neck, or stimulation of the superior cervical ganglion itself, was follomed, after a latent perlod; by a well-warked fall of intra-oeular tension; due to constriction of tha intra-ocaliar arterioles: this latent interval which oceus between the dilatation of the iris and the fall of tenston, strongly confirming the oplaion. that the fall is due to vaso-constiction; since, in the case of the ifls it has been shown, by Langley and Anderson their experinents that the eonstifiction of the arterioles follows the dilatation of the pupil after a distinct interval. Leber, on rabbits, and schaler, on cats, 
have both observed the experimental contration of the retinal vessels; following upon irritation af the cervical sympathetic.

When we come to seek for clinfcal proof of vessel-spasm; we are met with divergent opinions. Haab states that postive proof of vessel-spasm; in either normal or diseased retinal vessels; is largely wanting. Leber, and Wagenmann comment on the feasibility of the theory of vessel-cramp and the latter, recognising its importance, suggests further study of the subject. Hughlings Jackson, in his. work on the Brain, found that sleep is accompanied by an anaemia of the brain, due to arterial constrictiong and arso that this constriction could be observed at these times in the retinal arteries. This was confirmed by Mosso, Durhan and Kennedy; and Leonard Eill; the latter also riatinting that "we have overy raason to suppose that the retinal circulation is an accurate index of the cerebral circulation and vice versa."

The corretation of artertal retinal constriction with the fall of blood pressure has been noted in anaesthesia and narcosis. I have seen this naprowing of the retinal arteries very 
marked in a case of monphia poisoning; the fundus belng extremely pale, the disc white, and the arteries mere streaks, whilst the veins were rather f 411 .

A study of the visual disturbances sometimes noted after severe or repeated haemorrhage is also ingtructive, although many points in this dangerous but fortunately rare, disease; are still unexplained. Thy the loss of a similar, and nat necessarily excessive, quantity of blood in one individual shabla produce grave visual disturbance and in another not, and why sometimes both eyes and in other cases only one eye should be affected is still unknown. out of one hundred and sixty cases, collected by Fries from the literature of trorhundred and fifty years, "in eighty-nine and a hal 1 per cent. the visual disturbance was b1lateral and in sixty-ane per centi both eyes became blind."

\section{Many theories have been advanced to}

ezplain tt. Von Graefe suggested retro-oeular haemorrbage as a cause: Samelsohn assumed the propulsion of arachnoidal fiuid into the intravagtnal space of the optic nerve by an existing cerebral oedema: others bave attributed the 
symptons to inflammation of the optic nerves, to a disturbance of the circulation in the optic nerve and retina, and to rapid degeneration of the retinal vessels induced by the acute anaemia. Gowers states "that ane effect of the loss of blood may be upon the retinal elequents themsebves. Eaab is of the opinion that all these theories have been forced into the background by the anatomical researches of Ziegler. The latter resorts to the supposition of the local contraction of the blood vessels to explain the facts, maintaining that "a certain disposition, Which has its origin in a sensitive vaso-motor system, is required for its production."

The following is a case of this form of blindaess recorded by Lanford. A woman, aged forty-eight, had severe haematemesis, and becale collapsed. There was no recurrence of the haemorihage. The eyesight failed, and a ter partial reoovery sank to complete bilindess, which พxs permanent. ophthalmoscopic axamation revealed, in each eye; a very p.ale, hazy, slightly oedematous papillas surrounded by cloudy retina by which the veins, somewhat enlarged and turgid, were partially obseured. The arteries were 


\section{(26.)}

narrowed; no haemorrhages mere seen.

In the Hestern Infirmary; I observed

a very similar case in a noman, aged forty-five, sulfering from careinoma of the stomach. After Qrofuse haematemesis; she becane very collatsed; several hours afterwards she was stikl but semiconscious: the gupils were moderately dilated and did not react to light: Tension-1: she did not seem to have perception of light but this could not be accurately determined.. Ophthalmoscopically the discs are palef the retinae diffusely hazy, the arteries contracted, and the veins dilated and tortuous: slight pressure on the globe produced anifest arterial pulsatian and the current could be readily stopped by increasing-the pressure. The appearances, in fact, were simllar to those we so frequently see in cases of so-called embolism.

An explanation of this is suggested to me by a recent contribution by Mra Malcoln on "The Condition of the Blood Vessels during Shock." (Irancet Aug., 1905.) He traverses many af the usuelly accepted views on this subject and maintains that "a contraction of the arteries generaly, and espectally of the superficial arteries, 
occurs during shock" and "there is no complication more likely to precipitate a condition of shock than the loss of a considerable quantity of blood." He elaborates this theory of arterial contraction with great minuteness and conolusiveness.

If this view be accepted many af the clinical facts of shock are easily understood and, further, in my opinion, these instances of blindness following haemorrhage rasolve themselves (somewhat after the assumption of Ziegler) into cases of obstruction of the central artery of the retina from spasm of the vessel wall.

In the consideration of the Toxic Amblyopias we find that the belief in the existence of arterial retinal contraction is as widespread as it is authoritative.

In lead-oolsoning the amaurosis has been ascribed to a spastic ischaemia of the retina (Elshnig): Tobacco Amblyogia, according to Parsons, is the result of two chlef factors:

(1) a toxic effect on the nerve cells: (2) a vascular effect caustig vasorconstriction of the retinal arterioles.

$$
\text { Again, in Quinine Amblyopia and those }
$$
of the coal-tar derivitatives there can be littie 
doubt that the vascular condition is the essential factor. In the severe Quinine cases me have blindness, complete or incomptete, usually developed ith great suddenness; dilatation of the pupil, arked constiction in the size of the retinal arteries (with occasional obIiteration of their peripheral portionsl. Cases have :oven been described (Gruening, Buller, Browne, etc.) With "the retinal haze and the cherry-red spot, closely simulating cases of embolism of the central artery af the retina."

The experimental researehes of Barabaschea, Brunger, and de Schweinitz, show that - "there is primarily, an ischaema of the retionl and optic nerve vessels caused by their intense contraction," the former-believiag:that "this:is brought about by a condition of irritability of the vaso-motor centres; eaused by the Quining:" De Bono and Ward Holden admit this vasomiconstrtction but place great stress on the : arly nerve changes of rhich this permits.

In the ophthalmoscopic examination of the fundus during the Algid period of Cholera, contraction ot the retial arteries has been observed freguently. Von Graefe has even:seen 
cases "exhlbtting all the symptoms that may bo observed in embolism of the central artery af the ret in a." "

The occurrence of arterial retinal:spasm in Migraine has been doubted by some; but many of tbereported:cases hardly:adit of this doubt. In this connection Gowers states: "of great importance are the attacks of loss of sight lasting for a Ier hours or a day or tmo, occastonally observed in the subjects of Migraine, sometimes apart from the attacks, at other times in association with the pain. This fallure of sight; usually:transient, is souetimes permanent, almays In one eye only. The ophthalmoseoplc appearances are those of occlusion of the central artary:" (vide also,i Galezowski t Bec. d'ophe, Jan., 1882. Doyne - Trans. Ophth. Sac., Vol. IX, p. 148). Ckinically it bas been noted:in Migraine that the arteries on tho affected sideare aften the soat of arterio-gelerosis; this has been confirmed anatomteatly by: Thoma. Assuming then, that this affection: is, lo: the first stage. a vaso-aonstifion due to: a rasoritotor neurosis

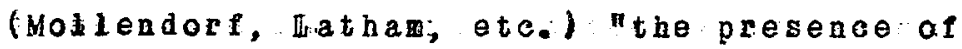
arterio-selerosis:1s: a point of interest beartig 
on this view." (Osler). Later an I shall:have occasion to refer to this association. Migraiae hag been considered by many to be: the sensory equivalent of a true epiteptic attack. Hence"in epileps, the question of arterial spasu has been frequentiy discussed. There: is much divergenee of optnton on this matter. Gowers states that ${ }^{\text {H}}$ no change:can be seen in the retinai vessels, eren during an attaek, at least of a tinor bature." Hughlings Jackson, on the other bandy describes a case ahere the retinal arteries suddendy d sappeared whtlst the fundus was beigg exambed at the the of the setzore. Swangy adits its occurrence, and so does Suckling. Doyen reports a case where, an trephining the sutil for epilepsy, the patient had a ftt during the operation; and it was observed that at its onset the brain became suddenly:anaemic.

The dificulties in the way of getting clinical proof of artertal retioalspasmin epjlepsyare, necessartly, very great. Dusing the past atghteen months, in the Giasgor: District Asylums, I have had many opilegies: under: care. One epileptic, allad of nineteen, usuaty 
complatued of loss of sight immedately:before the onset of a sefzure; duting a series of fits I ras able to make an ophthalmoscopic examination and I have no hesttation in saying that the furdus was pale, the arterles distinotly narrowed and the veins full; thus accoanting for the blindness, apart from the probability of a psyehical factor. In other cases, again, arthough there was no apparent abnornality in the fundus $Q r$ in the size - 1 the vessels yet arterial pulsation, and: in one case actual stoppage of the current, was obtalned by comparatively slight pressure; and this fact, i.d the absence of any demonstrable increase in fatra ocular tansion or general fall in blood pressure, polnts to some temporary interference wth the blood curreat, nost birely vaso-constrietion.

In Chorea there is an opportunity far the fovestigation of arterial spasm. Swazy has reported:a case (Royal: London Ophth. Fospital. Reports, Vore VIII, p. 181). nhere "embol:isq of the central rettal:artery of the lefteye, and chorea; chiefly of the left side of the body, came on simulaneously." It is interesting to note that no cause for the supposed embolus ras 
found, the beart: betng normal; no histary of rhenmats,nete. Benson reports a case (Tho Ophth. Rev., 1886) nhere three attacts of chorea

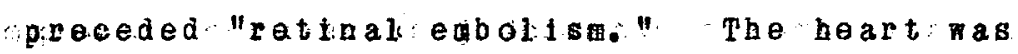
normal and no source for the 'embolus' was round, The interest of these cases lies in the fact that the embolic theory of chorea has been iargely disearded and; as Gowers says, is. now merely historical. Turther it has boen affirmed that, at least; some forms of chorea may bo due to prolonged arterial spasm. If this bo so, thesecases of arterial rettial obstraction, occarting on the same side as the chorea; "are tas.truetive, more especially as no source for an embolus was detected to warrant the dignosis. There are several cases reportedin which retinel lschaemia ocourea as a more or less. fndependent affection; the fundal arteries were found extremelythin, almostempty, and bareig vistble, the veins being broad and dark, and the paplifa paliid. (Graefe, Rothmann; Kapp and others). In thesecases there is no mention of any condtion: which pight have given rise to reflex arterial spasm: but in the interestiggase recorded:by Priestley Smlth; we have:very direct 
evidence of such a condition. Here: in connection mith:the use of:a raginal:syrtnge: and the touching of:a partieubar spot; sudden; but temporary, blindness repeatediy occurred, tili, on one occasion the eye temaned pertinently bind. Phe appearance of the fundus was "indistigutshable from embolism." Wagenann, also, reports a case where a patient suffered frot repeated attacks of blindness in one eye. ophthalmoscopically all the appearances of reeent 'embolism' were present'and yet after a lapse of ten minutes the circulation began to return; the vision, eventually, being quite restored. Some months later one such attack led to perwanent bitndness; with the ophthaleoscoplc plcture of 'embolism.' Benson reports a very similar case.

This retinal spasmay be either reflex or central. An lliustration; probably of the Jatter class, came under my own observation. whe patient mas a mangaged thentyifive gears, of neurotic temperament and a neuropathic ancestry. There was a clear history of acquired Syghils. His mental condition wasthat of Wi ld; but progressive; dementia; grabably 
secondary to syphiltic arteritis; which was mal marked. At infrequent intervals, he was subject to eplieptiform convulsions, and at these pertods he suffered from vaso-motor disturbances, such as marked pallor of the face; followed by flughing - usually limited to the head and neck but sometimes more general. on several occastons he complained of loss of sight. At one examination I found both pupils moderately dilated, the left being larger than the right: both pupizs were fixed: tension seemed normal: he had dim perception of form with the right eye and were perception of light and shade with the left. on ophthalmoscopic examination both: fundi were much paler than usual and sightiy hazy: the arteries wore consliderably reduced and the bload current anly detected as a sight rhythical reddening on pressure on the eyebali: the veins mere dark, fuller towardsthe periphery, and somentat tortuous. This condition realined of and on for several. hours and then passed"away, the pupils bocoming normal and the vision gradually returning. Apart from these mantestations I could never detect anythlng in the fundi that wight be called aboormal. In a few days tipe his gistion mas $\nabla_{0} \cdot A_{0} R_{*}=\frac{20}{30}$. 
V. A. L. $=\frac{20}{40}$, (wIth slight degree of uncorrected hypermetropic astigmatismt. In the constderation of thts case one must not lose sight of the iact that the man was suffering from aross brain leston: the vascular disturbances being due, prabably, to some temporary interference mith the Vaso-motor centre: his bilndness, in my opiaion, was pot central or psychical, but the:result of the spastic laterference with the circulation of the retina.

My reason for dealing at such length with the subject of arterial retinal spasm is due; in part, to my estipate of the importance:of the subjoct and aiso to endeavour to place its actualty on a firer basis: and when we consider the eydence here adduced, surelg, we may clain, wth due deference to Haab, that thereis gostive proof, experimental and clinical, of vessel spasm both la normal and d seased retinal: vesseis. 
REFERENCES.

Anderson. Journal of Physology, XIII, 1892.

Benson. The Ophthalmic: Eeriew, 1886.

Report of International Ophthal. Congress, Edab., 1894.

Blessig. archive fur Ophthalmalogie, Bd. VIII, I) S. 216 .

Bralley. Trans. Oph. Soc., Vol. I, p. 44. Doyne. " " " " Vol. IX, p. 148.

Ecunds. " " " " Vol: I, p..44.

Elschnig. Archiv. fur Ophthal., Vol. XXIV, 1892. Galezorski. Rec. d'Oph. Jan., 1882 .

Govers. "Medical Ophthalmoscopy," 1904.

"Diseases of the Nervous Systema."

vopk Gaefe. Arahir. Fur Ophthalmologie, Bd. V. S. 1859.

Haab. Noris $\&$ Otiver's "System: of Diseases of the gye."

"Atlas of Ophthalmoscopy.:"

H11l. "The Gerebral Girculation."

Jaeger. "Ueber Staar und Staar-operation."

Kern. "Zur Enbolie der Arterien Retinae."

Knapp. $\quad$ Archiv. fur Ophthal.gVol.. IV, p. 448 .

Zayper. "Accomitodation and Refraction of the Ege." 
REFREAES COnt

Langiay. Journal of Physiology, XIII, 1892. [y.aford.: Horris \& Oliver!s llsystem of Diseases af the Eye."

Landesierg. Ned. Surg. Rep., Sept. 8, 1880.

Litebich. Berliner medieinische Geselischatt. Magnus. Klinische Monatsehrift fur Augenhe11kunde, 1878.

Manz. Helmholtz's Festschrift, 1891.

Mosso. Centrabl. f. d. Hed. Wissensch.

Osler. "Principles and Practice of liedicine."

Parsons. "The Heurology of Vision," 1904.

"The Ocular Circulation," 1905.

Retmar. Archiv. fur Augenheilkunde, Vol. XXXVIII, 1899.

Raehlmand. Fortschritte der Hedielo, 1889.

Reid. Physiological, Anatodical and Pathological Researches, Edin., 1848.

sacbs. Arebive fur Augenheilhunde, Bd. XV.

Selnabel.

t1

I

If

". XV.

Sehneller. Archiv. fur ophthalmologie, Bd. VIII, I. S. 216.

Salkowsi. Zejtschrift fur rat. Med. XXIX; 1867. de Sehweinitz. "The Taxie Amblyopias:" 


$$
\text { (38.) }
$$

RETERENCES Contd.

Pries.tley Smith. The ophthalmie Beview, 1884.

Suckling.

"On Ep 11 epsy."

"On Periodical Headache or

Migraine."

Smanzy.

Royal London Oph.. Hosp. Reports,

V01. VIII, : . 181.

Thom a.

Wagenuan.

Tard HQl den.
"Pathologisal. Ana.tory."

Archivo fur ophthalmologie, 1892.

Trans. Amer. Ophth. Socd, 1898. 
$(39 .$.

SECTIOH II.

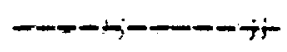

CASE I.

C. G., aet. 66 , housentpe, wt do.w.

Complained of loss of sight in the left eye of hall an hour's duration.

Patient was visiting the Glasgow textbition and on emerging frot a comparatively dim interior, sbe felt dazgled with the glare of the sunlight on the white valis of the bulldings. Recovering berself in a moment or two, she found that she had lost the sight of the left eye. She came to the Infirmary and was adoitted.

On examination the pupils were unequal,

the left being the larger: the left pupils also, seemed fixed: tension in both normal, though somewhat soft. Visual acuity in left eye = ivo pereeption of light: in righteye $=\frac{50}{40}$.

Ophthalmoscopic examation of the left eye.-

The fundus showed a high degree of retinal anamia: the arteries pere piliformand only the main branchos could be traced: at places they showed a white border. The velns were narrowed but nat to any great extent: this narrowing was 
most marked upon the optic aisc and they became relatively broader as they passed torard the ora serrata. : The optic papilla was of a pale yellowishwhite tint. The wacular region was khitish and the whole fundus very clearly seen.

In a. few minutes the inferior temporal. artery began to flll mitb a fine, broken column of blood: these little:cylinders oseillated and passed slowly on wards in a pulsatory fashion: it Was also noted that the blood colum in the corresponding vein had become broken and; with a to-andfro movement, was slowly emptylng - the vein becoming narrowed: slight paisation seen. After an interval of three or four anutes a little colubn of blood was seen to be entering the superlor artery, oscillating as it came, and at tiles alimost disapearing in the reverse direction, it reached higher and higher ug the vesiel: the onmard movement was distinctiy pulsatory. The neighbouring:vein behaved sitilarly to the inferior one. Very glight pressure on the eyeball emptied the artertes: the portions of the velus upon the alsc could also be emptied in this fay; whilst their more peripheral branches becare dark and engorged. Impediately on releasing pressure:the 
FIg. I.

case I. C. G. The fendus of the lett oyo

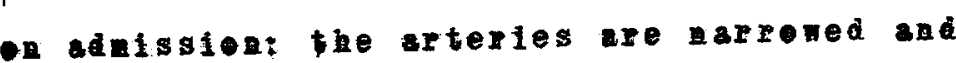
enly the main braches risible: tbey appear onty and at places show ahtio bordert the rolns ire alse narrowed and anovent whitish sppearane in the molar regien. 


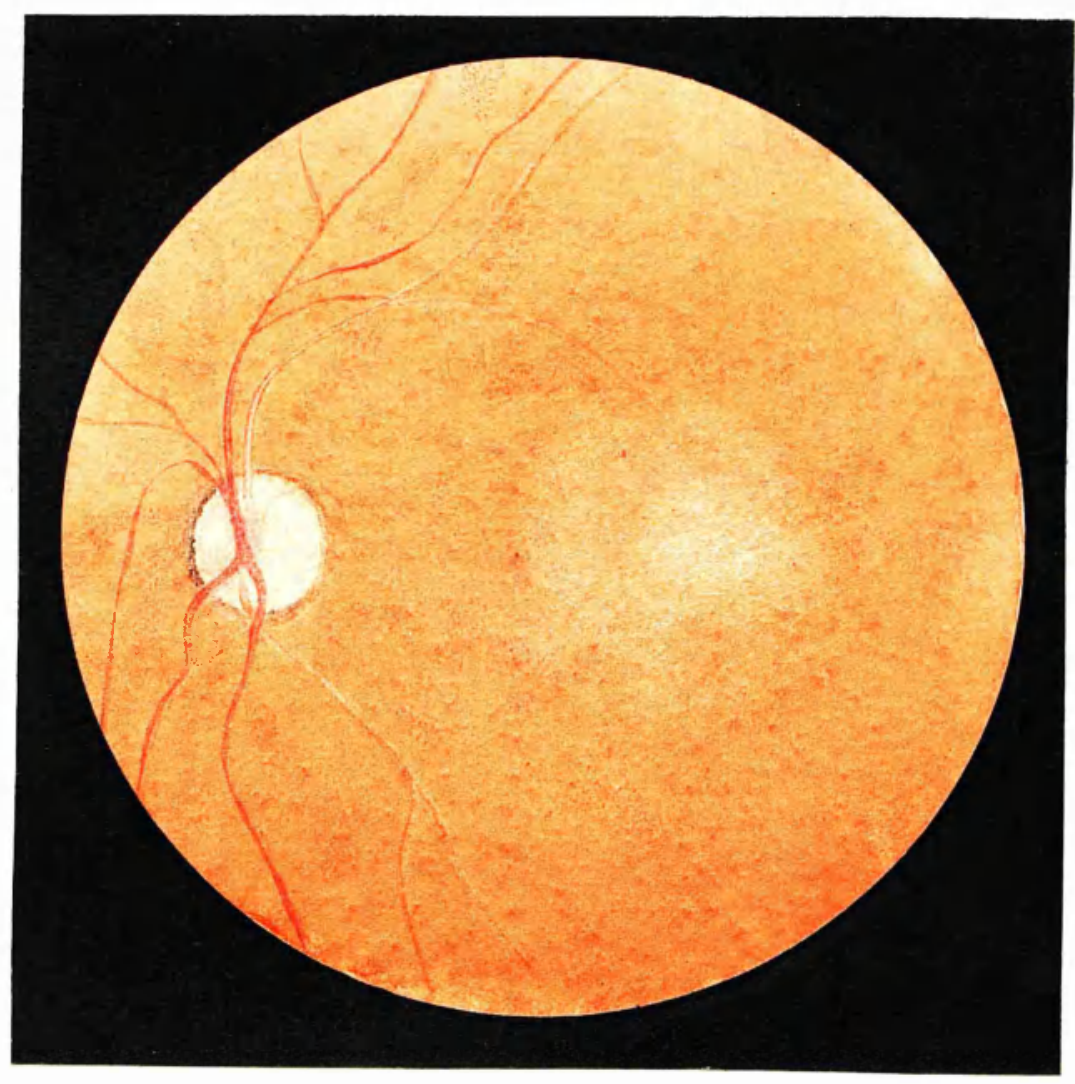

thenesen. 
blood cylinders quiekly ran into the arteries but in a moment they slowed and then behaved as previously mentioned. Prolonged massage bad an equaliy transient cesult.

$$
\text { During these observations it was. noted }
$$

that there was a rhythmical alteration in tho arterial retiol pulse: periodically: the movements of the blood cylinders became quicker and the pulsation stronger, followed by a gradual slowing and weakening: this cycke was present in the veins in a lesser degree. (For furtber observation and commentary see section III.)

$$
\text { About ten ainutes after the case cane }
$$

under observation the fundus as seen to be gettifg hazy, and the outrine of the disc blurred: by this time the cireulation had improred coasiderably and the blood current - still broken into cylindersWas runiug woh more rapidly and with distinct pulsation. As the oedema spread over the fundus the central area of the macular region, difusely red and about the sige of the dise, showed up by contrast = its margins fading lmperceptibly into the surrauding haze. Arteries and veins became ind Istingulshable and, eventually, al most bidden. No trace of haemorrhage had been noted. 
Arrangements being completed; paracentesis corneae nas done: but no immedate lmprovement in vision resulted. Meantiqe further ophthalmoscople examination as futile.

ophthalmoscopic exarination of the right eyeInspection of the right eye showed a dark sundus and a redish disc ith blured edges: the arteries were typically of the "silver wire appearance" and unduly tortuous: the veins were also tortuous and full; and at tmo places vistbly:obstructed by the overiylng arteries. The pigmentary disposition at the mactala suggested some disturbance there.

Family history:-

Father died:sudenly at lifty-four (cause unknown). Mother died at sixty from apoplexy. ifad only one brother; wo died at forty-eight from apoplexy.

Personal history?-

Marted and 1 domed: first three pregnanates ended in miscarriages: then two children werebarn but both: died in infaneye Has suffered much from chronic bronchitis during the past ten years: two gears ago she had a 'peculiar tunn' whoh was 
Pig. II.

Geze I. 6. $0 .-$ The fandas of the left oge twelve hors later: note the distribution t the cedenz and the opperance of the cherry-zed spot: the argin of the dise $1 \mathrm{~s}$ pery bluped: the arteries are ef larger ealibe and shen blood eylinders? tho veins we Fexy proninent. 


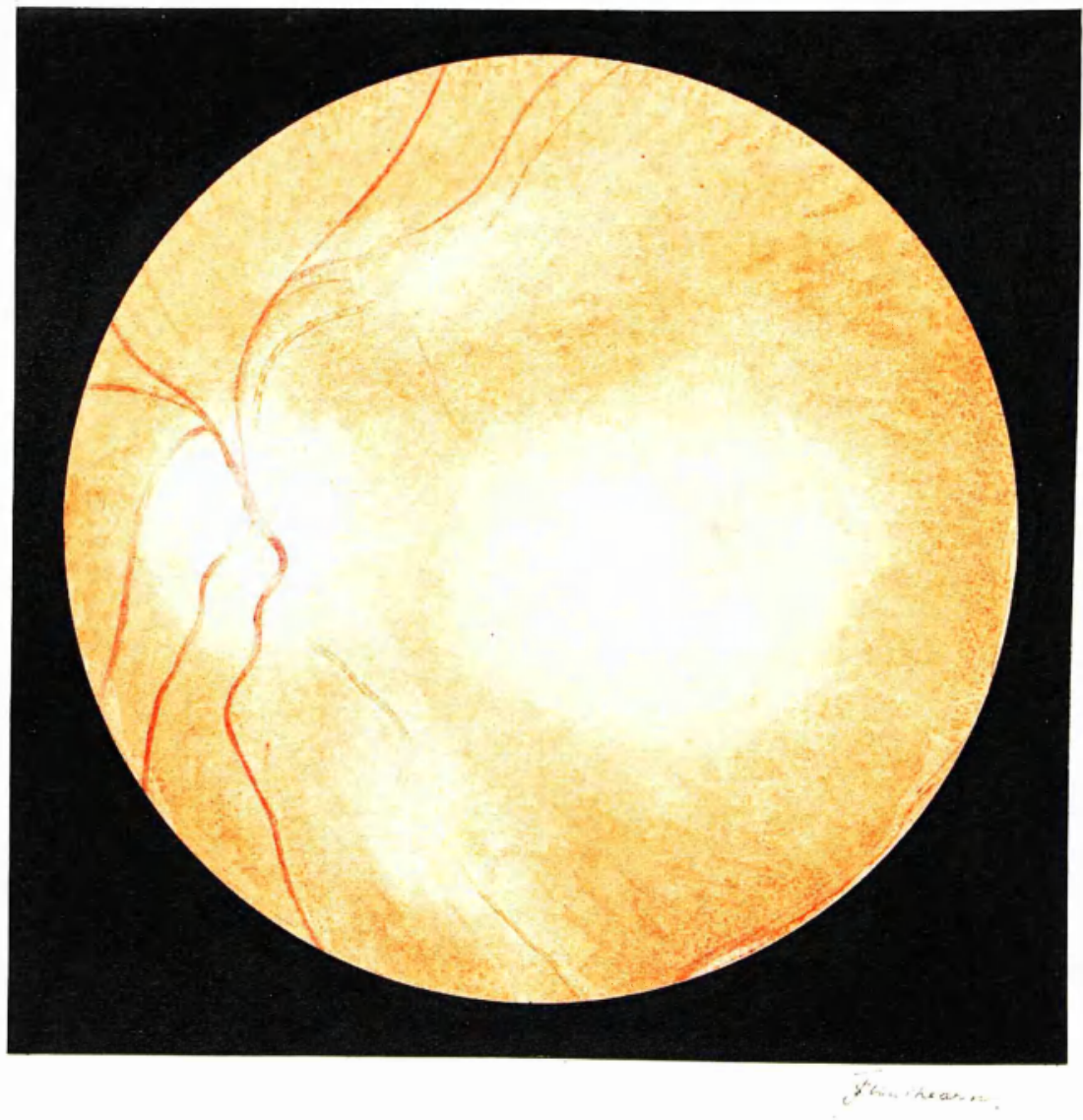


described then as 'a slight apoplectic stroke:' there was no affection of the limbs but she became giddy and confused and hal difficulty in spearing: this passed away in a day or two and she has had no recurrence: has never had any transient attacks of blindness in either eye, etc.

General Condition:-

Tall; obese and complexion pasty: Iipg showed slight lividity: the arteries (radials and temporals) were rigid and tortuous and the tension rather high: chest emphysematous and sigus of chronic bronchitis arked: no apparent enlargement of the heart and the sounds; though faint, seemed pure. Urine: sp. gr. 1024, acid: repeatedly showed a slight haze with the heat test: no tube casts found. No other abnormality.

On the follawing day ophthalmoscopic examination showed that the oedema was lessening: the disc was still very:blurred and its margins swallen: the macular region was paltid and oedematous: here the diffuse:redness,i alseady noted, was better demarcated: on wisute inspection a ring, a little smaller in alrcumference than the disc; and encloslog a slightly paler area, was seon and in the centre 
of this was a small red spot. The arteries were barely discernable upon the disc and their course was, in places, quite obscured. They now seemed normal in size and the blood stream; though stikl broken into cykinders; was woh more rapid. pressure on the eyeball readily interfered with the current, but it now required considerable pressure to stop it entirely. The veins appeared unusually prominent but aid not show wuch enlargement: the inferior branches were unduly tortuous and their peripheral portions dark and relatively full: pusation was obvious and tacrease of lntraocular pressure caused marked engorgement. There were no haemarrhages seen.

The last examination was made four ays Later; as patient as leavigg hospltal. The fundus was beginning to take on a dull opalue look: the posterior pole was greyish-fhite in tint and the red spot, delinited as before, was now dark redin colour. The arterles and velns shawed little change though, perhaps, the curpent was less. vigourous and more easily stopped: Percoption of light was still gutto lost. As patient lived at a considerable distance I have had no oppartunity: of making a 
further exarination but. I learned that the eye has remained quite bliad.

\section{CASE II.}

J. C., aet. 33, Iaflyay-man, singike.

Complained of lass of sight in the right oye of Pifteen hours duration.

He stated that eight days ago, while at work on the top of a waggon, unloading coal, the sight of hts Iight eye suddenly becare dimod. He bad no other symptoms and felt in the best of bearth. The vision was reduced to dim perception of light but after the lapse of a fen minutes it began to clear somewhat and three hours afternards only central vision was affected: he described it as "a ball of mist in front of the sight" and when ta looked at a face he saw the forehead and chin but not the central featuras. This gradually cleared, the misty ball getting sualler and sualler, and eight days after the onset he considered his vision normall. on the evening of that day his right eye 
again suddenly went quite blind, and next morning he came to the Infirmary.

On exagination the ight pupil was slightiy larger and reacted sluggishly to light: tension narmal. Viston was reduced to faint perception of light with a small part of his field. In the left eye vision was normal.

Ophthaimosoopic examination of the right eye.The fundus; as a rhole, was of good colour, the disc of an even pinkish-red, argins distinct exeept, for a small-part at the inner and lower edge, where the outiline was blurred and led into a hazy part of the fundus. At the outer side of the disc a quadrant-shaped patch of dark red fundus was seen, in size a little longer than the disc and three-fourths its breadth. The borders of this patch were fally well defined; the superior macular artery being seen at its upper and the tro branches of the inferior macular crossingits lover edge.. In the centre of this area, a cliloretinal artery was seen: it emerged near the border of the disc and disappeared before reaching the outer limit of the patch. Two large areas of oedema: were: seen: one situated below the disc and partially obscuring the oaln trunks of the inferior 
Fig. III.

Gese II. J.6.- The tundus of the right eje

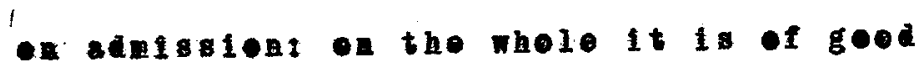
celon: note the distributio of the celems; and the area of the retina suplied by the etlie-retinal arteryt the arteries are not nakedig narroted and contan bloodt the relns are darker than nornal and atightig 12Eegulas. 


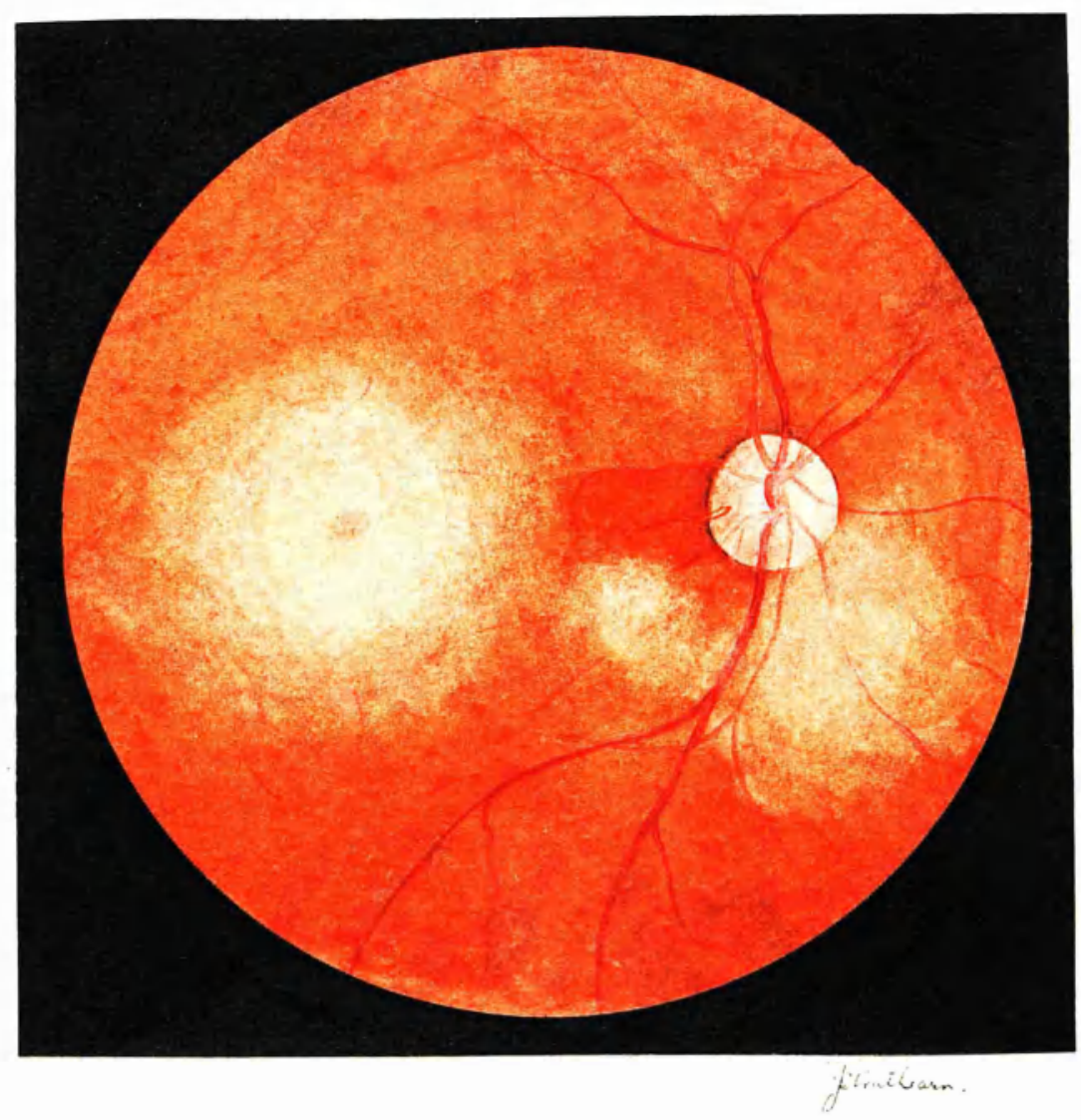


blood vessels, the other surrounding the thaular region: the macula itself appeared as a very falnt, diffusely red; spot; sorewhat oval in shape: it had a 'stippled' appearance; the centre slightly darker and the edge falmy abrugt: amid this oedema) surmounding the paeula, a circle of amall parts of tortuous vessels was just discernable. No haemorrhages were noted. Vessels. -

The ratio in size between the arteries and the veins is altered, but it is uncertain whether this is due to a slight constalion. in the arteries or to a sligt distension. in the veins. Both the superior and the inferior arteries are:imperfectly filled, and pulsation; espectally over the disc is well marked. On careful exalination the blood curtent is seen to be granular and tus along With a fluttering movement. on pressing the eyeball the arteries become thicker and redder and if the pressure:is incroased sueficiently, pulsation and aleculation can be stopped. The ailioretinal artery above noted, seons welk fllod: no qulsation can be detected and no alteration is -noted. In.it durfag the pressure exgerimants.

The veins are darker than normal and 
sifghtiy irregular in outline: just as they reach the disc's edge they becone lighter in colour and at the centre of the disc appear comparatively empty: through this light section a tiny stream of blood: runs in a riggiing fashion: very slight pressure on the eyaball stops thts current and dives the blood from the sections of the veins upon the disc. The blood in the veins is decidely granular; and pulsation noted.

ophthalmoscopic examination of the left eya.The fundus was of a dark-ed calour and shored a dity tesselation: the disc was 'flerg' and surrounded with a broad oboroidal ifig: both arteries and vains were skighty tortuous and very full in appeacance: the periphery of the fundus was arkedy plgmented, as was al so the macular region. No abnoriatities vere noted. Fanily bistory.-

Father living an well, aged fifty-eight: acther died In chitd-bed: tive brothers and one sister alive and well: one died in infancy and thee ตere. still-bora.

Persanal: Histary.-

Has almays been very healthy: at twenty had:a 
Tig. IV.

Case II. J.C.- The tundas ef the Iight eye

ter days latert nete the paller and the

censplenensnesg of the ebozry-red spet;

the artextes are paler and inperfeetif

f1lled the refis dar and tertgons. 


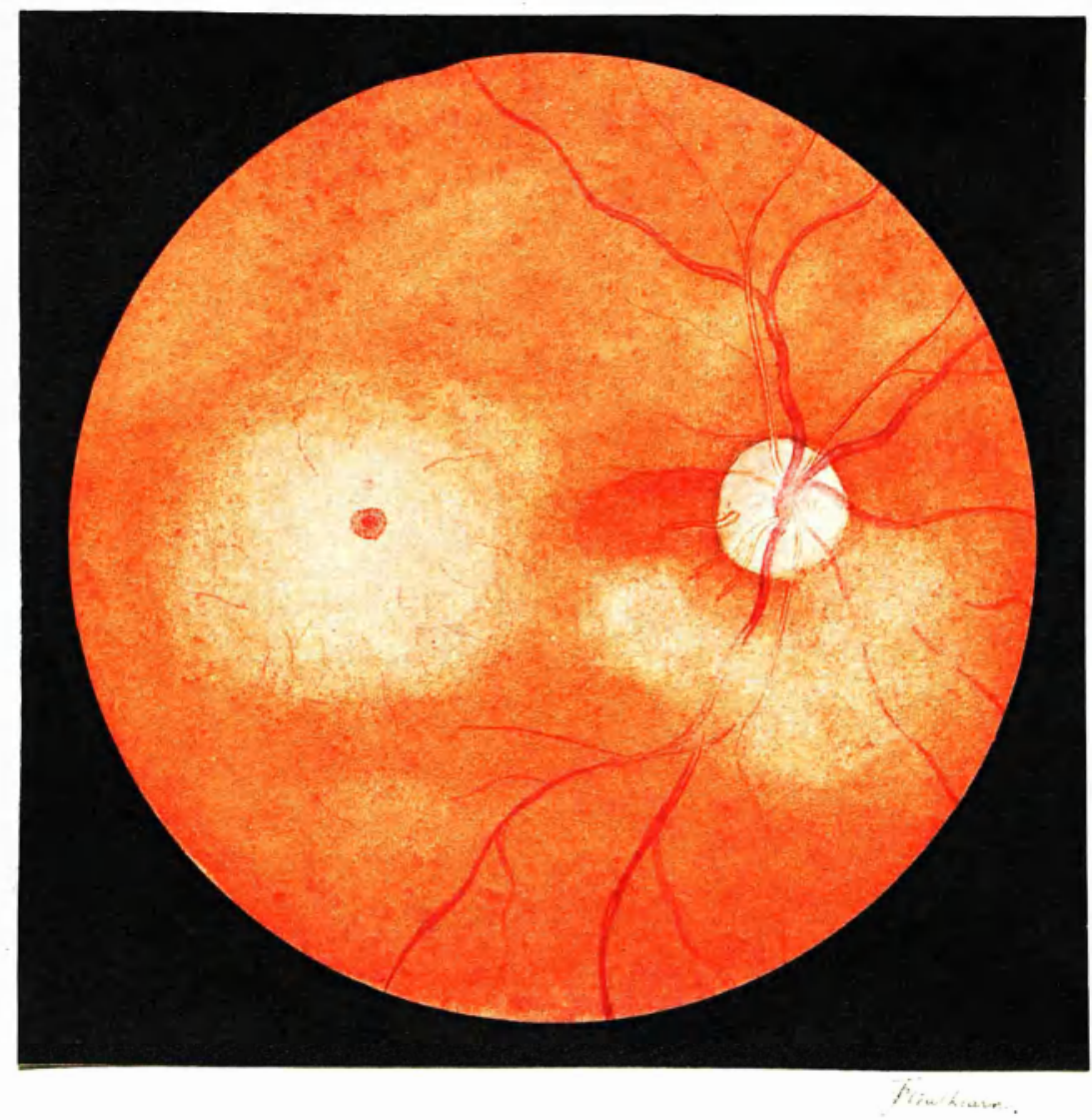


chancre, followed by the ugual secondarieg: drinks a large anount of alcohol.

General conditian:-

Strong, well;built, wuscular man: plorld.complexion: pulise forctble and moderately hightensloned: heart normal: second soud accentuated. Urine normal.

During the next ten days the fundal:condition showed little change beyond clearing somewat: his vision; however, had improved and he could now count fingers with a sall part of his temporal field. The day afterwards the superior temparal retinal artery was dim; a rrowed, and very imperfecty fibled: from its origin and for the length of three discs-breadh upmards; it appeared quite empty: on watching; however, one coujd see, at infrequent intervals; a ting and very granular; stream passing slowly up the vessel: on the other hand, the superior nasal fetinal artery mas mell filled and but slightly granular: prisation was detected on pressure. No noteworthy change in the inferior arteries, but all tbe veins mere becoming more engorged and swollen and presented a livid, lumpy look. The wacular region 


\section{T.}

Gase II. J. G. PeItineter chart of the right ore taken throe zeeks atter the enset of tho obstactian.

PE. FI.

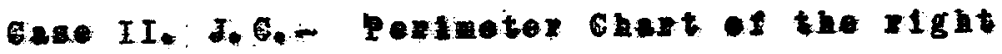
-ge ane year latert nete the ares of reletito reatonst 

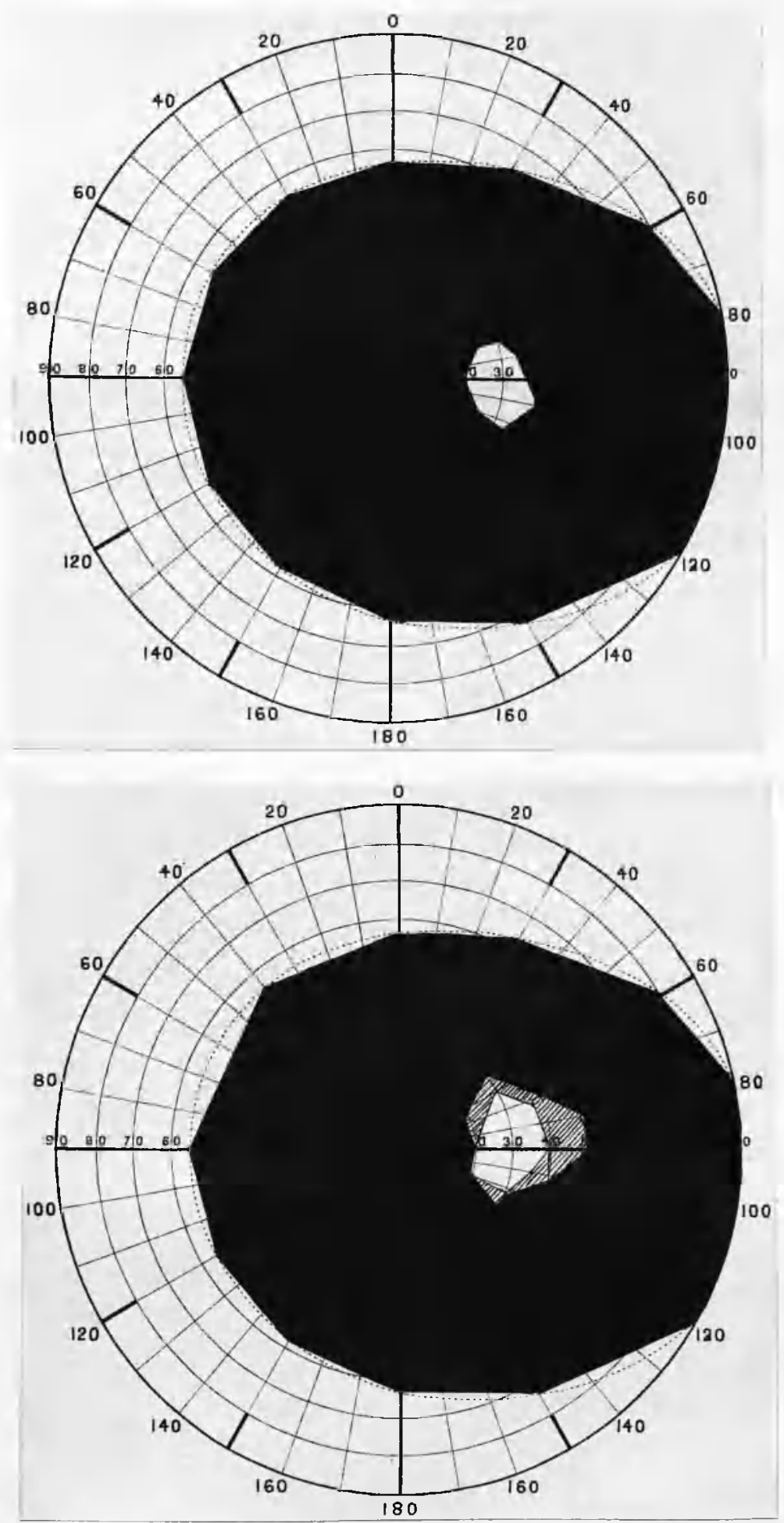
in them could be stopped upon the disc. It could not be safd that the cillo-retiaal artery nas visibly entarged.

Ten days: later the fundus was chear and of practically the same colour as its tellow: the retinal steiae were still. faintly seen: the disc was becoming paler: the whitish opacity in the macular region had disappeared and the macula itself Was of a brownish, granular appearance, and inferlorly to it were numerous brildiat; white pinpoint spots. The veins were full-but not at all. tortuous: the arteries seemed fatrly normal but it was noted that the arterial-pulse aould be more readily induced in this eye than in the kefto : $\theta$ n careful examiation of the arterial nalls I coubd nor satisfy mysalf that at places they were covered with small areas of greyish-white opacity: similar appearances could be detected in the left eye on minute tuspection. His visual tield has improved cansiderably, mare especially on the temporal.side, and he was able to read $\frac{20}{200}$ on Snellan's Test Type. When seen ane year tater the circulatory appearances rere still very similar: the ailioretinal artery had not increased in size: but two minute vessals, very tortuous, were now seen to 
accompany it. I was unable to determine whether they were arterioles or venules. The disc mas paler and its margins distinct; vision was certain ly not improved but patient thought. "the dimness was thinning."

\section{CASE III.}

J.K., aet. 54, engine-fitter, married.

Complained of brindness in the right eye of trenty minutes duration.

Patient bad just coased ark at dinner-time and on coming out of the door into the sunshine he suddenly 'felt giddy and peculiar:' aluost siuulaneously the sight immed:in both eyes: in a moment or two the vision quickly returned to the left eye and the gidainess gassed anay but the right eye remained quite dark. He came to the Infirmary and was admitted.

on examination the right pupil was semidilated and did not react to light: lept pupil normal: tensian in both normal. Visual acuity in right eye = Faint perception of light: in left eye $=\frac{20}{20}$. 
ophtbal Hoscopic exaniatiqu of right eye.-

Fundus rather pale, especially tomards the macular region: the dise was pallid wib margins elariy defined and the arteries rere thread-like and empty: the volus also looked empty and flata Pressure on the eyeball produced no change. In three or four minutes oedera of the retina began to show, the edges of the disc getting velvety and soft: in the macular region the disposition of the oedema caused the central spot to appear as a diffuse reddish haze, in size, samewhat karger than the disc.

Thinty-five rinates after the onset the return of the circulation as notedin the supertor temporal branch. Here, little cylladers of blood entered in a slow, jerky fashion, the current showing sinilar cycilc alterations to those noted in case I: at first the reverse naves caused the blood to ontirely disappoar at times, but it gradually mounted higher and higher until the whole Visible length of the artery shored a procession of osclliating blood cylinders. Shortly thereafter, the inferior temporal artery began to fill In a sinfler fashion but here the current as wuch slower and at tipes gulte stationary: whilst in 
this latter condition a definite, and perlodic toand-fro, movement was mantfested. The carresponding nasal branch shored siailar apeparances.

The veins were naw filligg up and becoming dark and uneven: the current was very slar and granular and only indefinitely pulsatory: pressure on the ayeball readily emptied thelr proximal.

portions and caused peripheral engorgement.

Two hours after the onset a sall stilate, flate-shaped haemorrhage appeared, just outside the disc and wid-nay between the branches of the superior temporal and the supertar nasal setinal arter18s. The pedena had steadily increased and was especially marked around the disc, along the larger vessels, and in the macular region. The circu13tion was gradually iaproving and the current, more particularly in the supentar temporal braneb, was now very rapid: the bittle cylinders rushed alog and were barelg separately distingulshable. Increase of intra-ocutar tension slowed the eurrent and elicited distinct pusation.

Soon the oedema became so marked that the vessels were in Iarge part obscured and, especially around the disc, the differentiation of arteries and veins was imposstbie. At this time (siz hours 
II. VII.

Case III. J.K.- The tandus ef the right eye

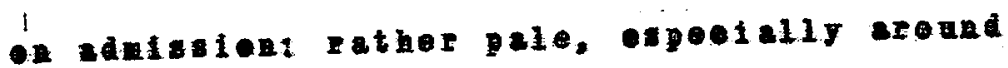

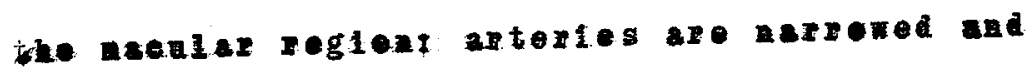

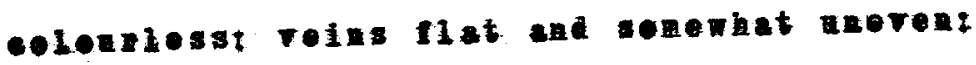
al the ressels meg the dise look emptye 


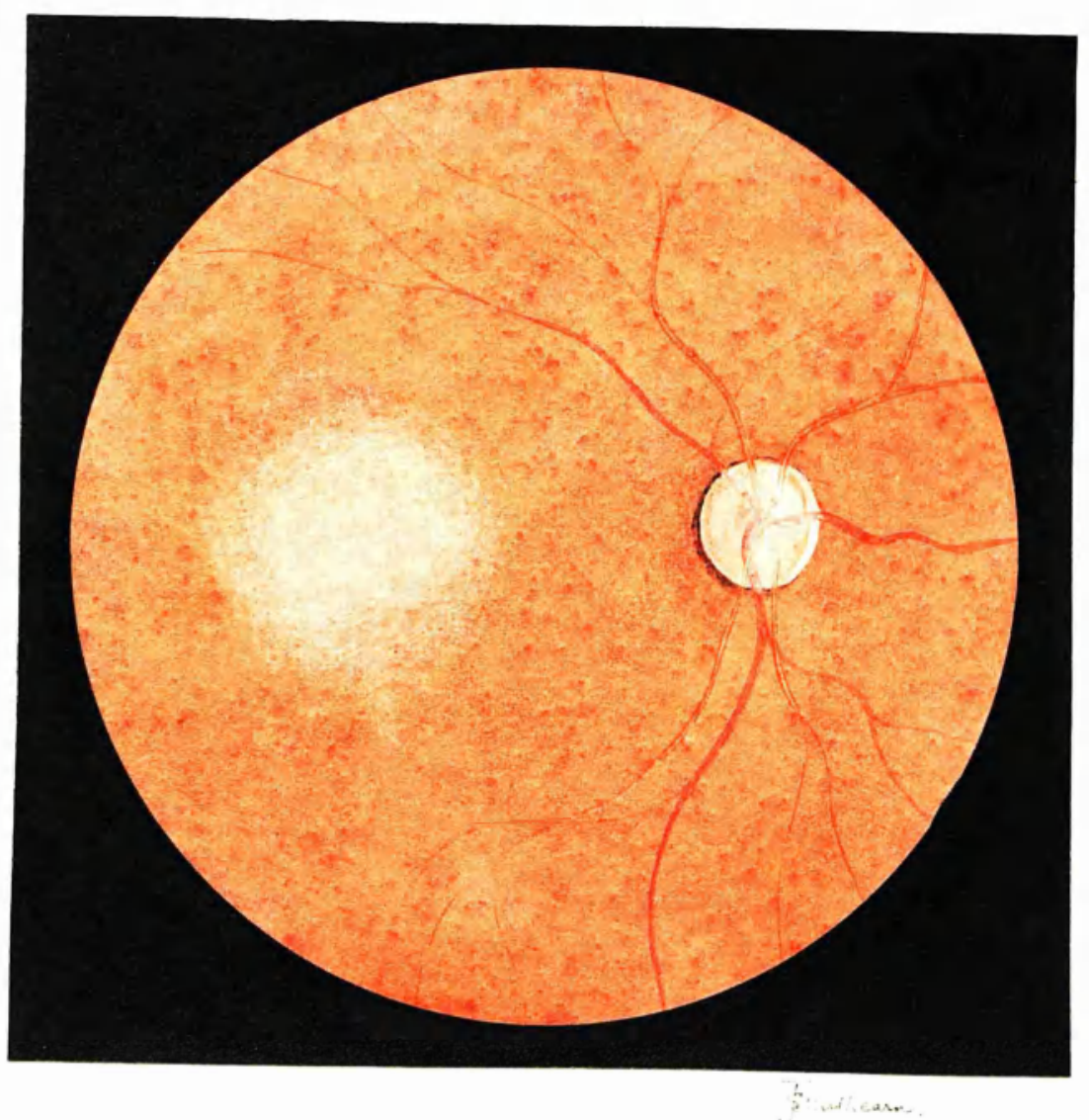


after the onset) further ophthalmoscopic examination of the eye was postponed.

ophthalinoscopic exalination of the left eye-

The fundus seemed healthy: no abormalities noted th the vessels: disc normal.

Family history.-

Wother died at thirty-eight in child-bed.

Father died suddenly at seventy-eight $\rightarrow$ ause unknown.

Patient was one of a family of three - the other two are alive and well.

Porsonal historym-

Had typhoid fever in chitdhood: othermise has always been exceptionaldy heatthy: states that he has not been a day of his work in thity years and a as in the best of heakth on the day he went blind. No previous visual disturbance.

Had six of a family - two dead, one from pneumenia; the othor, the result of an accident.

Is a total abstalner and no bistory of venereal. disease.

General condition..-

Patient looked robust and healthy: no abnarmality detected in the pulionary or vascular 
systems: urine normal..

Further ophthalroscapic examinations.-

Next day the fundus mas still remarkably oedematous but beyond this fact nothing further could be deternined.. On the folloning day it mas beginning to clear tonards the periphery and the outhline of vesselis could be dimly sten. Tro days Later the haze had cloared. wuetlaleatly ta permit af Eurther observation: what attrated most attention was a small, indelinitely flame-shaped, baemorrhage at the outer side of the disc. None of the vessels could be followed far and the arteries and veins were still. largely indistinguisbable. Six days after the onset a turther small. haemarkage. was detected, a ittlie above, and to the. Inner side of, the macula: it ras round and did not appear to be striate. The macular region was opaguely white: in its centre athin reddish ring, slightly larger than the disc, nas seen and in the midda of this a siall dark led elliptical. spot. The reins were dark, uneven and tartuous: the arteries still showed raptay. moving blood cylinders and pulsation was readily elicited on pressure. Paint perceptlon of light was non 
FIg. VIII.

case III. J. K.- the fundus of the light eye

'twenty lour hours later very bedenaterst

Tessens traed with diffientyt nete the

appearance of the moula, and the seall

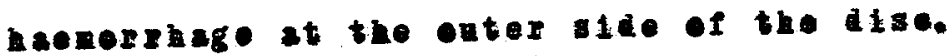




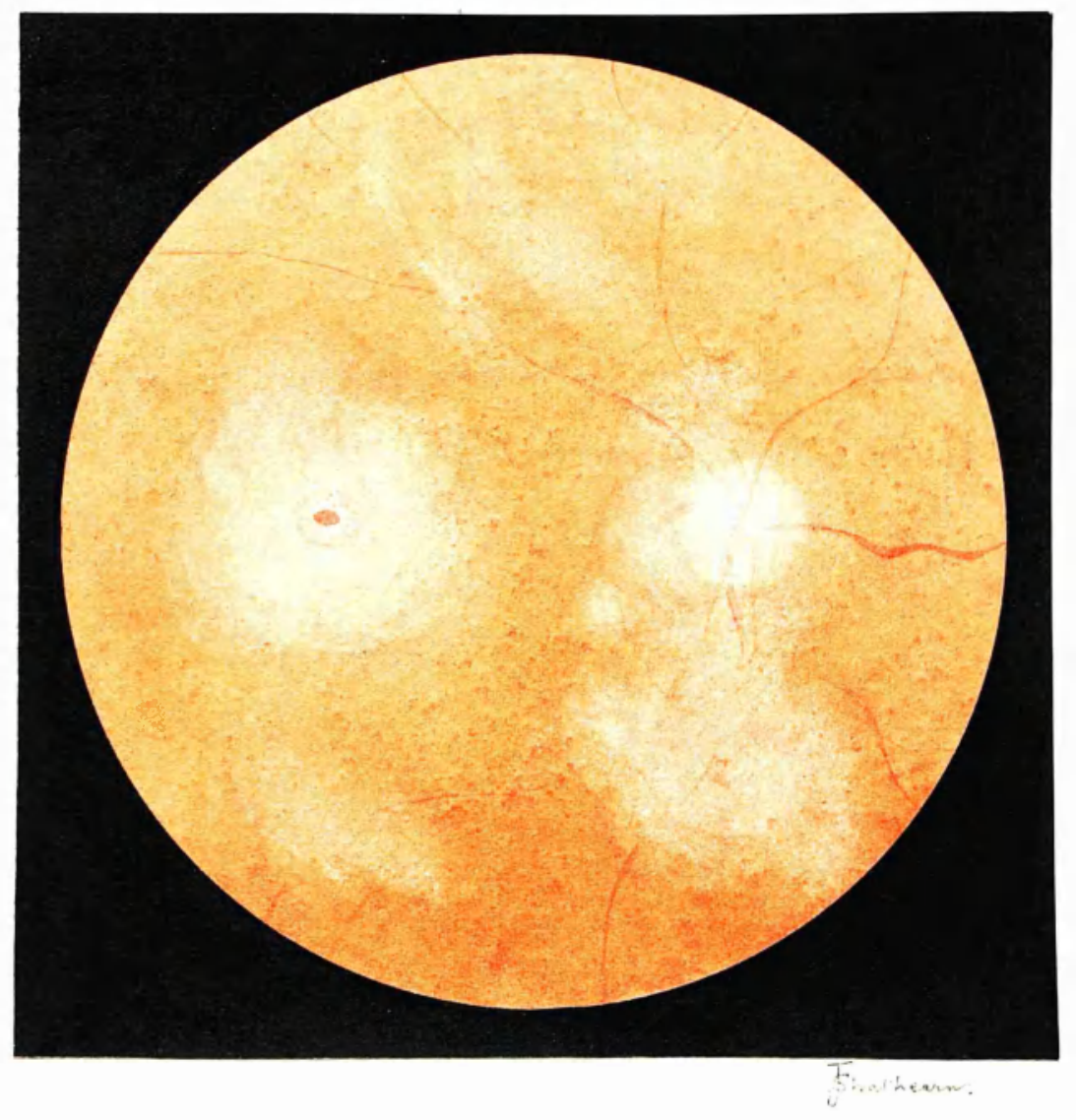


present. or this day patient left haspital.

ophthalmoscopic examiation one week later.-

The fundus was dull and op aque-looking

and showed traces of oedema in its lower hall:

the disc uas pale and yellowish and its nasal and

inferior.borders well defined: the outer side mas

still:meh swollan and obscured the vessels pasing over it: falnt traces of the two haemorrbages, noted bere, could stili-be seen. The superiar arteries were of good breadth and could be fallawed far up the fundus: they were very light in colour and empty-10oking: these vessels probably contained some blood, as marked pressure on the eyeball whitened them considerably. The vein was Larg; dark and uneven, being especialty smolben just before raachig the disc's border: uponthe disc it ras much narromer and pater. Puisation In the vein was easily elleited on pressute and imparted an eel-like movement to the ressel. : on account of the gedema, the lower vessels weremore obscure; the arterles shomed a falat circulation but no pulsation: the inferior velas exhibited apparances similar to the sugeriar branab. At the postertar pole there was a markedly paze area about 
twiee the size of the disc: eround this, and over its margin, tortuous vascular trigs mera very evidant. In the centre of this area mas a shebl. greyish-orom spot nith soft adges: the haemorrhage in this region was now only visible:as:a faint granular, oromish pigmentatiou. Perception of light in doubtil.

The tast ophthalmoscopic exanination I had the opportunity af making was about a yoar after this. I then Iound the typicak picture of retinal atrophy. The disc was a dirtygreylshwhite fith well defined pargins: the arteries were mere streaks becoming invisible tomards the periphery. The veins, whloh were tuch arromed, pursued a straight course.

There was no perception of light.

Examination of the let eye revealied no change:and vision has naral. 


\section{CASE IV.}

W. A.i, aet. 69 , watchman, single.

Compreined of bitadness in the lieft aye of four hours duration.

He stated that four days ago tho sight of the lieft eye became sightiy dimmed: it then cleared up constaderably but an the morting of that day had gone quite blind.

On exalination the pupils of both eyes were rathet small and did not react to 1ight: tension in both was normal. Visual acuity in the elght eye was :- $\frac{20}{40}:$ In the left eye there was no perception of light.

Ophthalmoscopic exanination of left oye.-

The fundus was pale but not markedily so:

the disc was of a dirty yeltanish-red tint, its nasall border being well defined but the temporal one oederatous and smollen: the arteries were reduced in sizej pale and enpty-looking: upon the discthe artartes seened quite bloodless: excepting the superior nasal branch; none of the arteries could be traced far; the superior temporal branch; a were redish streak; soon becoming invisible: the inferiar branch was of larger calibre but about a disc 
and a balf breadth down it was quite obscured in a pateh of oederia.

In marlied contra-distinction to the art

teries; the veins were very probinent and dark:

their outbine was uneven and irregular and in places mue narraned: upon the disc the vetns here braad; ampty, and of a bluish appearance: no puisation aoted. on pressure a falnt pulsation was seen in the inferior artery, exhibiting itserf as a slight rhytheical:reddening of the vessek wall: at the sane time the veins upon the diso became paler, whilst their more peripheral portions seemed fuller. One or two wacular twigs were seen On the disc and an the a as stde tro suall arterloles were noted, evidently branches. of the central artery of the retina, given of beforelts emergence on the papitra: There was an area of considerable oedera at the postanior polie of the eye and in the centre of this the red spat was faintly discernable. In the upper hat of the fundus therro nas ovidence of Jross retinal disturbance: "there was a triangular atrophic area in the course of the temporal branch and above the macular region: its borders were nell defined and showed reaent striate hamorrhages. At a corresponding site in the nasal 
Fig. IX.

cace IT. H. A.- The fundus ef the leit oye 1 on adnissien; tomperal border of dise eederatoms: antontes are reducod, pele, and enptyLookingt Jolng are ponlnet and ark, and or the dise, bread, opaque, and bluight nete tho zetinal distugbanes in the superier hall of the Inedes. 


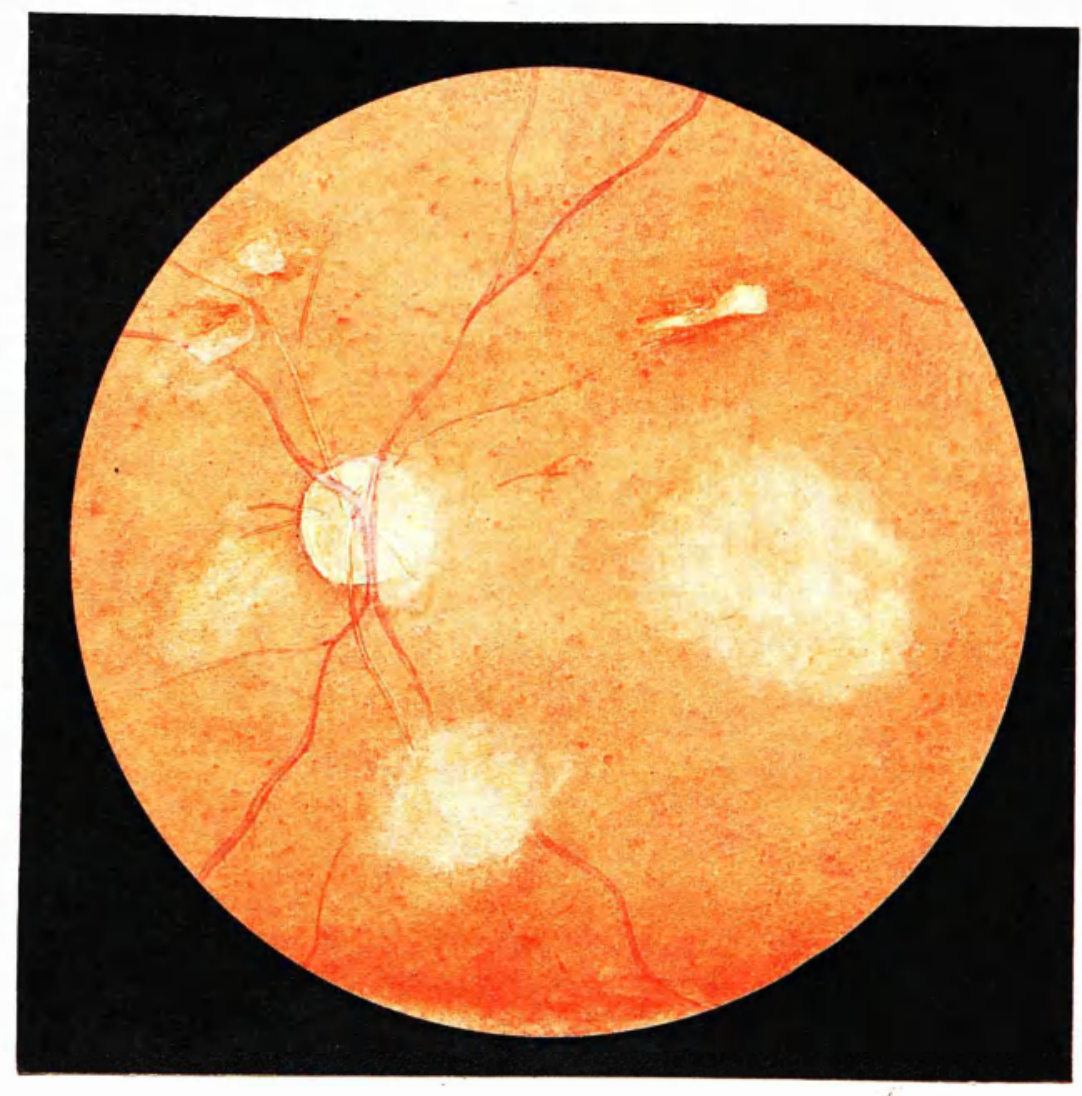

Atrothew ro 
balf of the retina were two simitar areas, one on either side of the superior nasal cetial artery: they mere smaller and not so deftate in outline: traces of recent baemarthege were notad around these spots.

During the time the eye was under observation a siall haemorrage had appeared at the upper border of the disc: it was flare-shaped and striate and during the examination labout tho hours) vary slanly increased in size.

ophthatmoscopfc examination of the right eye.The fundus shared cansiderable abnormalt ty: the disc ras hazy and yel lonish and its margins more blurred and swollen: tio arteries were light-coloured, the central streak being woll marked: they mere unduly tortuous and irregularly narrowed at places. The velns were uneven and shoned signs of the pechanical obstruction of the over-lying arteries. There fere evidences of old extparasations and the macula:shoned a faldet pigmentary motting.

Family histary:-

Father died at forty-five from a 'shock.' Mother died at thirty-seven in 'abild-bed.' 
Has four sisters and three brothers: ane sister died at fifty-six from apoplexy: no bistory of the others obtalnable but he thought they wene al ive.

Personal historyo:

Until within the past teri years be had almays been a very healthy man: was heary drinker and smoker and had led a very loose life: had gonorrhoea severat times but never aware of a chancre. About a year before this he suddenly last the sight of the right eye: the vision siowly returned during the nezt few reeks: three months later he had a recureent at ack of blindaess in the saire eye, and this time the vision did not retura so completely. Thare had been no previaus at taeks: at transient blindaess in the left eye and before the onset of this affection it was his "good eye."

\section{Generali.condition.-}

Talt and well-bu1lt: face flocid and blatohed:

marked hardenting and tortuostty of all the superticial. arterles, the temporals and radias belng:speetally affected. No abnormality of the heart deteoted. Urine - sp. gr. 1020. No albumin nor sugar. 
Fig. X.

Gese IF. T. A. - The fendus of the left ego twelre herrs later: palloz and ecdere new narked Volns protinent, ongorged, end tertuous: nete the obstrution in tho teferior nasal reneus branch due te an ereniglug ortery: the arteries, where seon, are naycered, bat eontala blect observe. 186, the small stgiate haenergage st the upper bezder of the dise, and the spoeraneo -1 the naena. 


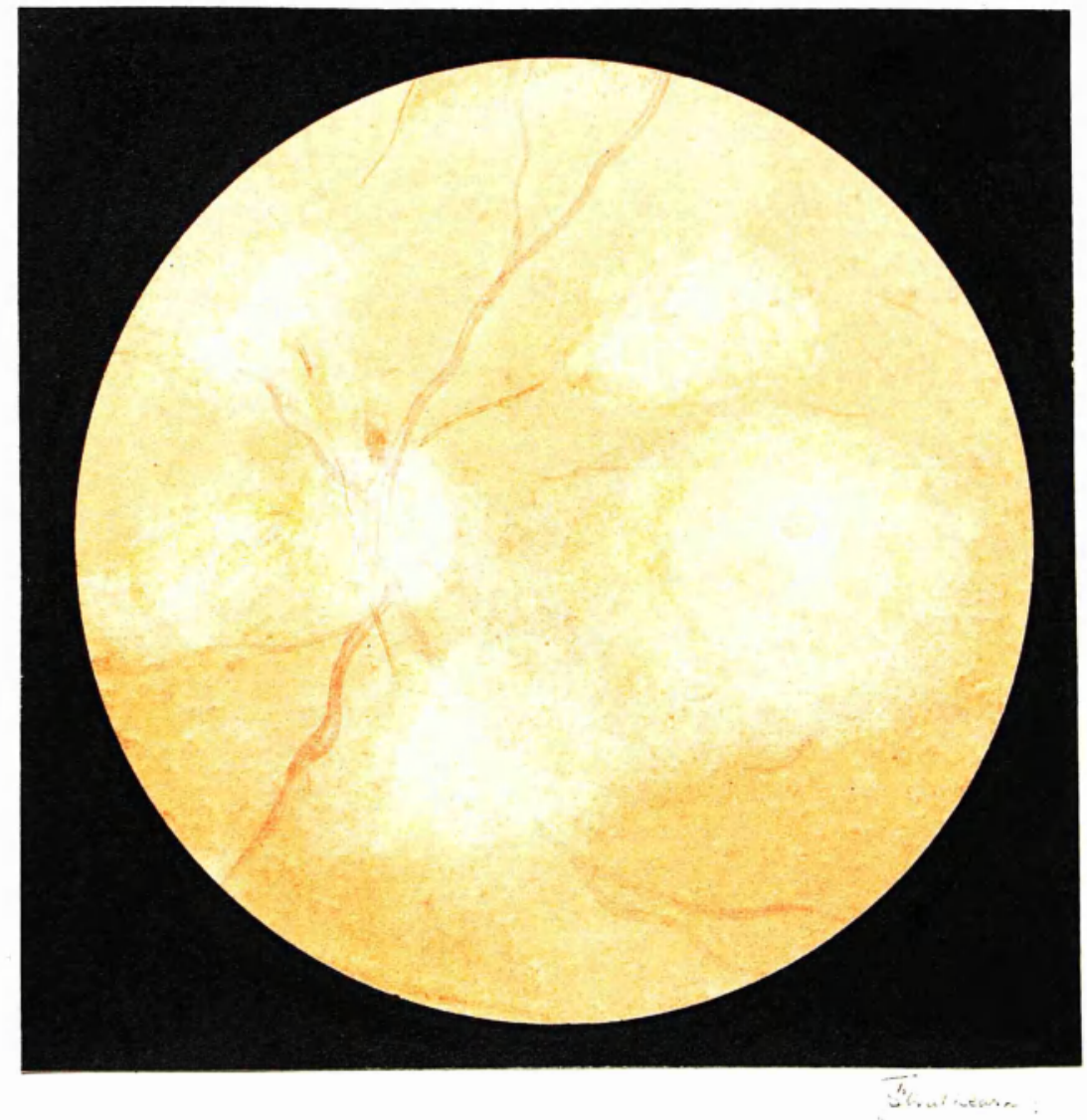


Next day the retioal oedema had greatly increased; being especially marked in the macular region and at intervals around the disc. The. smakl haemorrigage at the upper border af the disc was repy evident but bad nat obviausly increased in size. The vetns were broad; turgid and tortuous and the iaferior nasal venous branab was somewhat obstructed by the crossing of an artery. This vein mas repeatedly seen to fill up and then discharge over its paptllary portion in an irregularly pulsatory fashion: a sioilar, but less evideat, phenomonon was noted in the other velns. Distiact circulation and pulsation: aas noted in those artertes which were unobscured: moderate gressure on the eyebalil sufficed to stop the otroulation entirely.

Faint percietion of light with the uppor half of the field was now present. Patient lept hospital on tis day and the next examination (mhich piroved to be the least) was made five days later. I then foud that: the oodema was clearing: the disc was vecy pale and the arteries mere thraads: no evidenoe of circulation obtalnable. The vetns were dark, uneven and pulseless and marked pressure poduced no change. 
The haemorrage at the superior borde: of the disc was slightly larger; but no fresh ones noted. The 'cherry-red spot' as now seen as a clearly defined elliptleal redish-grey spot with a faint reddish halo sureouding lt: outside this the rest of tho mecular region nas opaquely whtte and against this background minute retinal:thigs were statkingly evident. The eye as now quite blind. Patient did not again return to hospitaband I was auable to trace this case further. 


\section{SECTION III.}

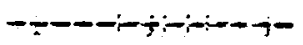

To formulate a diagnosis in these cases of obstruetion of the Central Artery of the Retina is a matter of some difficulty and complexity. So many conditions have to be investigated, so many factors weighed, that the temptation to cely upon the stereotyped diagnosis of 'embolism' is undoubtedly great. Yet; when we read many of the regorted cases, we canot but be struck ith the discrepancy bet patient and the hypathesis of 'embolism.' The physical exaination so often reveals nathing abnormal, the histary of the patient before and after the Qcaurence so uneventul that the idea of the sudden appearance of an lsolatod amolus, and its fopaction in the central artery of the retina, seems tar-fetched and tanciful. Further. in those cases whera'we have:a history: of visual or cerebral df sturbance, priar to the onset of the affeotion, any explanation basod on the embalic theory seers improbable and fadequate.

In seation. II, I have given raports: of faur cases of so-called emboligm-a heartiesian 
was not discovered ta ang. To what, then, wust we look for a cause for the obstruetian?

Let us oonsider first the mode of:onset 10 thesecases. : In cases I end III the blindness was sudden:and permanent, no previqus at tacks of transiant blindness in either aye: $:$ in both; the onset mas accompanled by a simutaneous affection of the other eye and signg of cerebral disturbane: How could an embolus, minute enough to enter tho centrar artery, cause all this disturbanoe"and if thore nere several emboli why mas the action of the others so:transitory?

\section{In Case:II (J.C.) we have:alstory: of} an attack of blindnoss in the same oye eight days previausly - the sight gradually retarafag antil. he thought his vision normal again, then a recurrent attaok. Here, agata, the heart was normal; the vessels, on the other hand, shawed changes and tho higtory of syphilis and alcoholism mas definte. If thts be accegted as a sufticient"souree for an embalus we are met with the diffiealty of oxplatning the previous attack, with gradual but compete recovery, and the fact that hen fist seenthere was a distinet pulsating curpentin the vessels. 
ity: the arteries, however, were markedly rigid and he ras a heavy:dinker. There as aistory of two prewious attacks of temporary betadness in the other eye: (eventually, leaving the vision

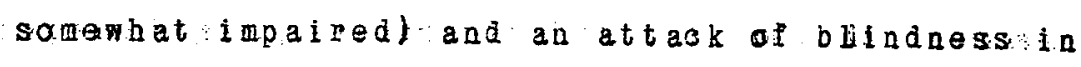
the same eye four days bofore. Can the theory of embolism as the causative factor be accepted here? In the condition of the vessels:we bave:a probable source for such a plug; but, in viea of the histary of attacks of prodromal periadic blinding, I consider this:hypothests largely untaable as well: as Imprababke.

The theory of Patmary Thrombosis I have previousty considered and feel:constratad to regard the idea of thrombosts,as the primary aftection, quite inapplicable to the great wajority of the cases: as a secondary process, honever, it must be regarded as of the greateat impartanoo. In arterial disease we hare: factor common to three of our cases and in the other (Case III) ne cannat negative itsexistence As wes. sh, this may act fimarily, and cause obstruction, : either by obliteration of the lumen or by a naproming, sufficient to perit of the inetdental approxillation of the vessel inalls. That is, doubtioss, 
a ptobable explanation of our cases. But, perhags, arterisl disease acts more commonly through tho occurrence of lntfmak changes, so: that thrombosts, under certain circumstances, readily develops. Hence artertak disease, or throubosis secondary: to arteriat disease, might explatn:the cllateal tats of these cases; and Haab goes so far as stating that obliterative endarterftis, or thrombosis, is the usual cause (emboltsm, in his opinion, being very rarel.

In Cases I and II the history of onset differs in some important particulars from the others. In both the bilindness was sudden and complete, and accompanied by a very transient obscuration in the fellow eye, with slight cerebraldsturbance. In Case I these symptoms were very slight and described by patient as "a dazzling:" in the other case (Case III) the simultaneous disturbanoe was more definite and lasteà langer. In view of the posstbitity of retlex retinal arterial spasa, we must bear in mind that both were affected by the sudden action of brifgt sunilght; the patients, themselves, attributed their blindness to this cause. This polnt is worth constdertig. Apart from the photo-chemtcal action 
in the retinal erements, it may be that the sudden effect of bright hight on the retina is to cause (in certain cases, at least, some degree of replex vaso-constrtction. Fhen: bright light is shone on the retina (bitherta in darkess):it has been noted that, in rare:cases, the puptl. sudenly contracts but almost imediately ailates to some extent: then either gradally and regularly, or with a hippus-like action, slowly contracts - the time occupied being very variable, for less than a minute to over an hour. I have on a faw. occasions observed this in the exafination of the eyes in the insane; this reaction is supposed to be more common in this class and in those of a neurotic temperament (Julor, oppenbeim). As the p.Imary contraction and the subsequent dilatation is often very sudden, it is sometimes orerlooked and the puplis considered as not reacting to light or reacting very sluggishly.

This phenomenon is known as Paradoxical Pupillodilatation. Wuch experimental work has been dono on this subject. Budge (1855) first called attention to its occurrence after section of the left symathetic and of the branches above the right superior cervical. ganglion in a rabbit. 
Kowalewsk1 (1886) observed it in a kitten after the administration of chloroform. Langendorf $(1900)$ has noticed the phenomenon after anaesthetics and after death; the latter and surmioski explkatned the reaction as being due to the cantraction of the vessels in the iris. Hence nay ne not conjecture;in those cases: where it is demonstrable, that the light, primarily causes a reflez contraction of the pupil but almost simulaneouslya vaso-motor constriction (through the actian of the sympatheticl: and that this action of tho sympathetic counteracts the pup $11=c 0$ atraction, so leading to sque degree of dilatation?

Howewer this inay be there: is evidence enough: to show that in thosecases of spastic retinal obstruction, due to a general cause, the pupils are dilated (sect. 1. - retinal spasm). Further, cases I and.II also showed thts difatation in the affected eye, gradually passing of 1 in the course of a few hours.

In conoection ith the probableaction of sunlight an lnteresting case is recorded-by Dr. Rayner Batten (ophth. Soc.. Jan. 31, 1901):

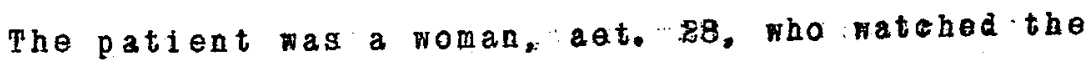
eclipse of the sun on May 28, 1900: immediately 
thereafter, she noticed that the sight of the left oye was dark and the next morning found that she could only see "portions of things." First seen on June 6 and found to have:iost the lower half of the field of vision of the left teye. Above the optic disc a white patch:was seen, probablyian absorbing haemorrhage; whist the hazy and oedematous retina obscured the view of the disc and vessels. The oedema increased until. June 20 and then rapidy cleared. one of the upper retinal arteries was occluded and the other reducedin size. Patient was in good health and no other cause for the affection could be found, except exposure to sunlight, which Dr. Batten thought had:induced thrombosis of the retinal arteries. He offers no explanation for the pccurrence of this arterial thrombosis nor does he:state whether he thought it primary, or secondary to some other condition. Before leaving this part of the subject, I should like to give an excerpt froll a reported case of imbolis of the Central Artery of the Retina following Parafin-injection for Deformity of the Nose (Drs. Hind and Bolden.-Medical Becord, July 11, 1903). The patient was an Itallan, aet. 32, and the deforitity was probably syphilitic. 
At the third operation the neodle, for injecting the paraffin, was first introduced at the tip. of the nose and pushed ugwards and then tntroduced at the rogt of the nose and pushed donnards to a spot just above the former injection. At this point the patient rubbed his ight eye and stated that he could not see with it. Some ecchymosis appeared at the tip of the nose, indicating the puncture of a vein. The ophthalmoscopla exaination was made twenty-five minutes theraater. The pupil was then large and did not react:to light: no perception of light present: media clear: netioa clear and veins seemed norial: the inferior arteries were expty and collapsed; being recogntsable only br the faint outline of their Falls. The superior arterial branches contalued blood cylinders and gentle pressure on the eye was sufficient to empty the vessels. Tro hours later, the disc had become blarred snd the retina hazy: the oedema increased and the red spot at the macula was clebrly seen. The loss of vision perststed.

No further particulars are given. As as said; this was reported and has been stuce:commented on, as a case of embolism of the central artery of 
the retina,dueta blockage by a silall-paraflin plug. Ta admit of this diagnosis, wo nogt presuppose that the plag entered a sill vein in the nose - reached the heart - found its way into the arterial system through some such abnorWity as a perforate septum ; and then eame back to lodge itself in tine central artery of the vetina! Surely this explanation ts far-fetched; - to my mind this case is more explicable as one of reflex arterial retinal spast, and the fact that the qupil was dilated and did not react to light favours this view. The patient was,probably, syphilitic and secondary thrombosis might have, eventually, occurred.

\section{In the consideration of cases:I and} III, we must bear in mind all these points;. and after carefully considering the mode of onset, the early symptoms, and the general condtion of the patients before and after the occurrence, I an of the opinion that these:cases were probably, pritiarily, spastic in origin. Doubtless, the presence of artertal changes etc. bad soing part; not only in its determination (vide-spasm in Migraine and Raynaud's diseasel-but also in the 
eventual, permanent blockage - whether thrombotic or proliferative.

The blindness in cases of obstruotion of the central artery of the retina is, as a rule, complete and almost instantaneous;. in to of our cases the bilindess was complete but the other two had faint perception of lisht when first seen. The obscuration, however quick, is generaliy in a centripetal direction; occasionally, it takes place in a centrifugal wanner, as in the previous attack of Case II.

In none of the cases was the intraocular tenston appreciably diolatshod. This is the rule and is usually explatinad by the fact that the ciliary. circulation is still intact; that·is, doubtiess, a sufficient explanation.

The appearance of the arteries is very variable and great differences are observed. If seen soon after the onset of the obstruction:(as. in cases I and III), the larger arteries are markedly narrowed and the smalker ones:intistie. Frequently, they appear to be quite empty and most authors describe them as such, but:it is difficult to believe that any obstruction of an 


\section{(84.)}

artery could be so complete as that; under the blood pressure, either a tiny strean of blood or liquor sangulais would surely be forced through. The veins, on the other hand, do not show such marked changes. On the disc they are often narrowed and empty-looking - becoming efther relatively, or actually, broader tonard the periphery, They show an uneven calibre and sometimes present ampuliform sirellings;. they are darker:in colour than norial.

It is someshat difficult to understand why the latra-ocular tension does not foree the blood out of the veins, after the arterial blockage. Parsons considers this ta be the post potent factor: "the ocular venous tension is lowest at the disc, so that the velns are stopped here firgt by the extra vascular pressure, and the blood is dammed back."

The re-establishment of the eirculation is of great interest. From the recorded cases t seems to take place at very varying pertods - from less than an hour to several days. In Case I, the inferior temporal artery began to fill: wh a broken column of blood within forty minates: in 
case. II a similar return was noted in the superior temporal branch thirty-five minutes after the anset; (in Cases II and IV the circulatory return had taken place when they came under observation). Almost sifultaneously a manifest circulation was noted in the veins - in Case I the blood column becoining broken into cylinders and in Case III, having merely a granular appearance. In no case did the stream move in a reverse direction to the normal blood current (ofcourse, excepting the reverse wave in the cyclical alternations - to oe afterwards commet ed on). As any of the recorded cases, where this reverse current is noted, ald not come under observation until some tire after the onset of the obstruction; Te wust accept its reported occurrence With reserve. I have already stated, in the report of my cases, that, after tho commencement of the retinal haze, the differentiation betweon arteries and veins, especially arround the papilla, became extremely difficuit and occasionally quite impossible; hence, unkess a case is noder continued daily obseryation, errors are almost unavoidable. The phenomenon is undoubtedy guch rarer than is supposed but has been described jy Jaeger, von Graefe, Mayerhofer, von Hippel, Hirschbers, Perles and others. 


\section{(88.)}

The breaking of the blood column into cylinders, or becoming visible granular, is of interest and of somewhat obscure origin: some vessels show a tiny stream of red blood, others show blood cylinders of varying size and movement, while others again exhibit mere granularity. In our cases the cylinders first appeared at the initial portions of the vessels but cases have been described (Gowers, Fuchs) where pressure on the eyeball. broke the continuous blood column into separate cyllnders. Our knomledge of the physiology of the blood and blood vessels is not suficiently exact to positively explain these and all led phenomena. As Felch points aut, the absenee of Lateral pulsation may be a factor of great importance. The circulatory eanditions are peculiar; and the physical properties of the blood, in relation to its viscosity and the presence of suspended particles, which readily stick togethery have to be taken into account. In the experimentale research of welch and wall, in the mesenterie circulation of the dog, they observed, in the velus and caplliaries, "interrupted cozumns of compacted red corpuscles with interventng clear spaces whteh are sometimes clumps of white corpuscies, sometimes 
of platelets, sometimes only elear plasma." Although this experimental blockage was arterial, there is no mention of similar appearences in the arteries. In the retinal arteries, when the curnent is static or greatly reduced, the corpuscles evidently undergo some physical change and show a tendency to clum - and the absence of the normal pulse-tiaves prevents the breaking up of these masses of corpuscles. However; I have noted that in those arteries which show a continuous stream of cylinders in their initial portions ibeir peripheral parts exhibit a corpact blood column. So, perhaps, the question of eapiliary attraction and the ratio of the quantity of flud to the calibre of the vessel ought to be taken into account.

\section{A pulsatory advance of these cylinders} in the arteries is not often noted: this was observed in Cases I and III; in addition, a rhythoical alternation of this pulsation was observed (vide section II): This phenomenon is of interest and, so far as I can find, has not been previously commented on in cases of this kind. Physiologically, rhythmical alternation of the venous pulise upon the disc has been observed (Wadsworth and Putnan). 


\section{(88.)}

the cycle of stronger and waker periods in the pul:se, corresponding to about five respiratary movements. This perlodic pulse must originate from causes independent of the eye and recalls those changes in arterial tension, noted by Traube, Hering, Meyer and others. It may result either from some rhythmic alternation in the blood pressure (Traube-Hering waves) or from rhythmícal movements of the arteries, as observed, experimentally, in the ears of rabbits, by Schiff. In Cases I and II it was most evident in the arteries at the commencent of the circulatory return mhen the current was appearing as broken cylinders but not showing a continuous circulation. Under these circumstances, the opportunity for its accurate observance was great and, considering the almost comlete suspension of the influence of the general blood pressure in these arteries, our observations. seem to favour the theary that they ary be, in part at least, dependent on sope rhythmical maverent of the arteries themselves. The subject is worthy gf further study and these cases of obstruction spear to offer facilities for this.

The time of onset of the petial oadema is very variable. Schnabel and Fischer have seen it tro 
hours, and ittendorf three hours, after the obstruction. As usually stated, it may come on in a few hours but occasionally not for some days (Gowers): In the classical case of von Graefe the opacity did not come on until the eighth day. In Case I, 1 t was noted forty minutes after the onset; in Case II it was present at the firstexamination - ilfteen hours after the onset;. In Case III it was noted twenty-five minutes after the onset; and in Case IV it was present at the tirst examination - made four hours after the onset. The distribution of the oedera is anatofical, being dependent on the thickness of the retine, and hence most inarked around the pap 111 a and $2 t$ the gosterior pore of the eye.

Eaemorrhages sometimes appear co-inetidentIy with the increase in circulation and enlargement of the caltbre of the vessels. The haemarrhages occur in the vicinity of the disc and in the macular region, and, as a rule, appear from three to five days after the onset of the affection (Haab). They were seen in tho of our cases (III and IV): In Case III, two hours after the onset, a small haemorrhage appeared just outside the superior border of 
the dise; Two days later another small haemorrhage ras seen at the outer side of the disc and six days after the onset; a third haemorihage was noted in the macular region. In case IV, a small haemorrhage appeared at the upper border of the disc. during examination, five hours after the onset;: no others were observed. Haemorrhages are not very compon and Fischer found them noted only forty-seven times in one hundred and fifty five reported cases. To explain their infrequency, the intra-ceular pressure, may be (among others) a contributing factor (Weich).

The red spot on the macula bas been regarded by Fuchs, in some cases, as a haemorrhage and he states that he has repeatediy convineed hisself of this. Graefe's explanation of the cherry-red spot was to ascribe it to the contrast between the white opacity of the retina surrounding the macula and the red chorioid shinlig through at this, the thinnest part of the retina. Blessig regarded it as a haemorrhage in the retina and Steffan as a haemornhage situated, behind the macula, in the choriold. Nettleship considered it as due to a circumscribed central chorio-retinttis. 
Fischer explains it as being merely the pigment of the retina itself. Elschnig thinks that both the retina and the chorlold take part in its production. The consensus of oplaion seews to be that the production of the cherry-red spot is essentially a contrast effect - the pedina of the inner layers of the retina stopeing short of the fovea centralis (where these layers are absent) and leaving.this part a oright red colour; this effect may be heightened by a hyperaemia of the choriold due to an increased circulation in the ciliary arteries, consequent on the obstruction of the central artery. From observations on its development and appearance in our cases this view seems the most likely one - as its regular and ofttimes geometric disposition is certainly not consonant with the idea that it is either a haemorrhage or a choria-retinitis. one of our cases (Case II) was complicated by the presence of a cilio-retinal artery. The frequency of this in normal eyes, according to Elschnig, who ex anined one hundred and seventy persons is seven per cent. These arteries are derived from the scleral vessels (the clrele of Zinn) and have no corresponding veins. 'Eaqueur 
collected sixteen cases of obstruction of the central artery of the retina, complicated by the presence of cilio-retinal arteries; the visual fields of these eyes were small, oval, triangular, or oblong, and extended from ten to twenty degrees in their horizontal diaceters. In Case. II, the perigeter chart, taken three neeks after the obstruetion, shows a borizontal diater of fully fifteen degrees: the chart taken one year later shows a slight increase to twenty degrees and a smal area of relative scotowa surnounding it.

As to the large and debatable question of the estabitsheent of anastomosis in these cases; clinical oxamination is of little assistance. Amid the great retinal changes that ensue after obstruct1on, decisive information on the enlargement of vessels or on the appearance of new ones, could hardiy be expected: against the atrophic retiaa

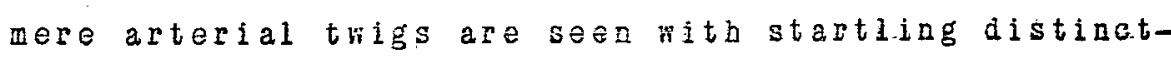
ness and on the gallid disc little vesselsterstwhile ingisible, now make a notable appearanco. However, there is no doubt that the terminal branches of arteries often appear almost normal whilst their initial stems are mere red threads upon the disc; 
if this be due to the establishment of a collateral circulation we have, as get, no anatomical knowledge of any such connection - bocause the chiep anastomotic communcations between the ciliary and the retinal vesselis take place among the vessels of the optic disc: out the appearances noted; noud require (if anastomotic) communications; not at the dise but towards the periphery.

\section{CONCLUSION.}

In this dissertation. I have deatinith a subject of general medical, as well:as special ophthalmological, interest. Its probloms are the problems of Medicine and their solution, its solution. And, finally, I ckaim that sufficient avidence has been adduced on: the etiology of this subject to narrant the discontinuance of the indiscriminate diagnosis of 'erbolist' and, whilst ariting further knowledge, to replace this term by the less definte but non-comittal degnosis of "obstruetion of the Central Artery of the Retina.n 
EUERTENCES.

Juler. "Ophthalmic Science And practice," 1904. Oppenheim. "Diseases the Nervous System, "1904. Budge. "ueber die Bewegung der Iris,"

Braunsehrig, 1855.

Komalewski. Arch. slav, de Biol, I, 1886.

Langendorff. Klín. Monatsbl. 1. Augenheilkunde, XXXVIII., 1900.

Surminski. Zeit. f. rat. Med, XXXVI., 1869.

Batten. Trans. Oph. Soc., 1901.

Hind. Nedical Record, July 11, 1903 .

Holden. Wedical Record, July 11, 1203.

Mayerbofer. Inaugural Dissertation, 1873.

Hischberg. Centralblatt fur praktisch

$$
\text { Augenhellkunde, 1884, s. } 71 .
$$

perles. Centr. f. prakt. Augen., 1891, s.237.

Schnabel. Jeber die Embolie der Arteria

$$
\text { Centralis Retinae, Lelpztg, } 1891 .
$$

Fischer. Ueber Embolismus, 1891.

Mittendorf. Trans. Amer. Oph. Soc., 1892.

Gowers. "Medical Ophthalmoscopy," 1904.

Blessig. Arehiv. fur ophthal. Bd. VIII., S. 225.

Steffan." " " "Bd. XII.;1, S. 46.

Nettleship. Royal London Ophth. Hasp.Repts.vol.VIfI. 
REFERECES Contd.

Elschnig.. Archiv fur Augenheilkunde.Bd. XXIV.,

S. 140 .

Liqueur. Archiv fur Augenhellkunde, 1895, Bd. XXX., S. 75 . 